\title{
Seasonal inhomogeneity in cloud precursors over Gangetic Himalayan region during GVAX campaign
}

\author{
U. C. Dumka ${ }^{I^{*}}$, Deepika Bhattu ${ }^{2}$, S. N. Tripathi ${ }^{2}$, D. G. Kaskaoutis ${ }^{3}$, and B. L. Madhavan ${ }^{4}$
}

${ }^{1}$ Aryabhatta Research Institute of observational sciences (ARIES), Nainital, India

${ }^{2}$ Department of Civil Engineering, Indian Institute of Technology, Kanpur, India

${ }^{3}$ Department of Physics, School of Natural Sciences, Shiv Nadar University, India

${ }^{4}$ Leibniz Institute for Tropospheric Research (TROPOS), Germany

[E-mail: dumka@aries.res.in; dimitris.kaskaoutis@ snu.edu.in; snt@iitk.ac.in]

\section{Running title: CCN properties over Gangetic Himalayan region}

\begin{abstract}
Atmospheric aerosols are key elements in cloud microphysics, the hydrological cycle and climate by serving as cloud condensation nuclei $(\mathrm{CCN})$. The present work analyzes simultaneous measurements of number concentration of $\mathrm{CCN}\left(\mathrm{N}_{\mathrm{CCN}}\right)$ and condensation nuclei $\left(\mathrm{N}_{\mathrm{CN}}\right)$ obtained at Nainital, in the Gangetic-Himalayan $(\mathrm{GH})$ region, during the frameworks of Ganges Valley Aerosol Experiment (GVAX), June 2011 to March 2012. The $\mathrm{N}_{\mathrm{CCN}}, \mathrm{N}_{\mathrm{CN}}$ and activation $\left(\mathrm{AR}=\mathrm{N}_{\mathrm{CCN}} / \mathrm{N}_{\mathrm{CN}}\right)$ at $0.31-0.33 \% \mathrm{~S}$ (supersaturation ratio), exhibit significant daily, monthly and seasonal variations within a range of $684-2065 \mathrm{~cm}^{-3}$ for $\mathrm{N}_{\mathrm{CCN}}$, $1606-4124 \mathrm{~cm}^{-3}$ for $\mathrm{N}_{\mathrm{CN}}$, and $0.38-0.60$ for AR, suggesting large inhomogeneity in aerosol properties, types and sources, which control the degree of aerosol potential activation. Thus, transported aerosols from the Ganges valley and abroad, the boundary-layer dynamics and atmospheric modification processes play an important role in aerosol-cloud interactions over the $\mathrm{GH}$ region. The $\mathrm{N}_{\mathrm{CN}}$ and $\mathrm{N}_{\mathrm{CCN}}$ show monthly-dependent diurnal variations with afternoon maxima due to transported aerosols from the Ganges valley up to the Himalayan foothills, while the AR is lower during these hours implying lower hygroscopicities or smaller sizes of the transported aerosols. The dependence of $\mathrm{N}_{\mathrm{CCN}}$ on $\mathrm{S}$ is highest during Dec-Mar and lowest during monsoon (Jun-Sep), suggesting different aerosol chemical composition. Comparison between Nainital and Kanpur shows that $\mathrm{N}_{\mathrm{CN}}$ and $\mathrm{N}_{\mathrm{CCN}}$ are much lower at Nainital, while the similarity in AR suggests aerosols of similar type, source and chemical composition uplifted from the Ganges valley to the Himalayan foothills.
\end{abstract}

Keywords: Cloud Condensation Nuclei, Activation Ratio, transported aerosols, Gangetic Himalayan region, Ganges Valley Aerosol Experiment *Corresponding Author: Dr Umesh Chandra Dumka, ARIES, Manora Peak, Nainital E-mail: dumka@ aries.res.in; ucdumka@gmail.com 


\section{Introduction}

Cloud condensation nuclei $(\mathrm{CCN})$ are hygroscopic particles that can activate at various supersaturation (S) levels to cloud droplets. CCN are thus key elements of cloud microphysics, the hydrological cycle and climate from local/regional to global scales (Lohmann and Feichter, 2005). The ability of particles to be CCN strongly depends on their size distribution and chemical composition (Fitzgerald, 1973; Pruppacher and Klett, 1997; Dusek et al., 2006; Lance et al., 2009; Srivastava et al., 2013). Furthermore, cloud microphysical properties, such as cloud-droplet size, cloud albedo and lifetime, cloud-top height and precipitation rate are influenced by the prevailing $\mathrm{CCN}$, thereby affecting the climate system (Twomey, 1977; Pruppacher and Klett, 1997; Ramanathan et al., 2001; Andreae et al., 2004; Rosenfeld et al., 2008). Aerosol-cloud interactions (aerosol indirect effect) are still a significant source of uncertainty in climate modelling and dynamics (IPCC, 2007) due to complicated cloud microphysics phenomena, their impact on radiative properties, precipitation and the hydrological cycle (Andreae and Rosenfeld, 2008). As a consequence, $\mathrm{CCN}$ measurements and knowledge of their spatio-temporal evolution are challenging tasks to quantify the aerosol indirect effect on climate.

Over the last few decades, emissions of anthropogenic aerosols and pollutants have dramatically increased over the Indo-Gangetic Plains (IGP), India because of the rapid increase in population, industrialization and urbanization (Lawrence and Lelieveld, 2010; Lu et al., 2011). Despite the availability of numerous studies on aerosol optical, physical and chemical properties over IGP and Gangetic-Himalayan $(\mathrm{GH})$ region (Jethva et al., 2005; Tripathi et al., 2005; Dumka et al., 2008, 2014a; Dey and Di Girolamo, 2010, 2011; Lawrence, 2011; Srivastava et al., 2011; Kaskaoutis et al., 2012), extensive measurements and analysis of CCN are still sparse given their role in cloud formation. Recent studies (Patidar et al., 2012; Srivastava et al., 2013; Bhattu and Tripathi, 2014; Ram et al., 2014) over IGP, using both ground-based and airborne observations, have reported significant seasonal variations of $\mathrm{N}_{\mathrm{CCN}}$ with maximum during winter and minimum during monsoon. Furthermore, the findings from a recent campaign "Cloud Aerosol Interaction and Precipitation Enhancement Experiment (CAIPEEX)" constitute an important contribution to this research over a climatically sensitive area, where the onset, intensity and duration of the monsoon affect climate, ecosystems and the economy (Chakravarty et al., 2011; Dipu et al., 2013; Padmakumari et al., 2013).

The current work deals with measurements of condensation nuclei $\left(\mathrm{N}_{\mathrm{CN}}\right)$ and Cloud Condensation nuclei concentrations $\left(\mathrm{N}_{\mathrm{CCN}}\right)$ obtained through the Atmospheric Radiation Measurement-Mobile Facility one (AMF-1) deployed at Aryabhatta Research Institute of observational sciences (ARIES), Nainital $\left(29.4^{\circ} \mathrm{N}, 79.5^{\circ} \mathrm{E} ; 1958 \mathrm{~m}\right.$ above mean sea level), during the intensive field campaign Ganges Valley Aerosol Experiment (GVAX; Manoharan 
et al., 2014; Dumka and Kaskaoutis, 2014; Dumka et al., 2014b). Air mass back-trajectory analysis via the Hybrid Single Particle Lagrangian Integrated Trajectory (HYSPLIT; Draxler et al., 2012) model and variations in boundary-layer height are examined to investigate the role of transported aerosols and upslope airflows on aerosol-cloud interactions over Nainital. Moreover, simultaneous measurements of $\mathrm{N}_{\mathrm{CCN}}$ and $\mathrm{N}_{\mathrm{CN}}$ obtained in Kanpur, located in the central IGP, during June-August of 2011 are also analysed and compared with those at Nainital to explore the spatio-temporal and altitude dependent $\mathrm{CCN}$ properties over the $\mathrm{GH}$ region.

\section{Observation Site, Instruments and Data}

\subsection{Site Description and Meteorological Parameters}

In-situ measurements of $\mathrm{N}_{\mathrm{CCN}}$ and $\mathrm{N}_{\mathrm{CN}}$ were carried out during June 2011 to March 2012 at ARIES, Nainital, which is an elevated (1958 m) site located in the central Himalayan region approximately $\sim 300 \mathrm{~km}$ northeast of New Delhi (Fig. 1). Nainital, with negligible industrial activity and a population of about half a million (census of 2011), is an excellent site for monitoring background aerosol concentration as well as long-range transported aerosols (Dumka et al., 2010, 2011).

Weather conditions at this site can be classified into four seasons: winter (DJF; December-February), pre-monsoon (MAM; March-May), monsoon (JJA; June-August) and post-monsoon (SON; September-November) (Dumka et al., 2010). During the frameworks of the GVAX campaign, the average wind speed was $2.33 \pm 1.75,2.02 \pm 1.39,2.26 \pm 1.49$ and $1.83 \pm 1.28 \mathrm{~m} \mathrm{~s}^{-1}$ during winter, pre-monsoon (only March data), monsoon and postmonsoon, respectively. Northwesterly stronger winds that dominated most of the time (late post-monsoon to March) are responsible for the transport of air masses from arid/semi-arid regions of northwestern India, Pakistan and west Asia (Jaidevi et al., 2011). The percentage of southeasterly monsoon winds increased during the monsoon, and continued to be high during September, leading to heavy rains and aerosol washout. During the post-monsoon, stable atmospheric conditions prevailed over the site, while in winter, western disturbances favoured some rain and/or snowfall in January and February. Seasonal temperature (in ${ }^{\circ} \mathrm{C}$ ) ranged from 17 to 26 (with mean $20 \pm 2$ ) in JJA; 9 to $26(17 \pm 3$ ) in post-monsoon; 0 to 24 $(10 \pm 4)$ in winter and 4 to $27(15 \pm 5)$ in March. The average relative humidity (RH in \%) was highest during the monsoon (> 90\%) and minimal ( 45\%) during March, while rainfall from June to September accounted for more than $85 \%$ of the total rainfall during the study period.

\subsection{Condensation Nuclei (CN) and Cloud Condensation Nuclei (CCN) measurements}

$\mathrm{N}_{\mathrm{CCN}}$ and $\mathrm{N}_{\mathrm{CN}}$ were measured by the Atmospheric Radiation Measurement (ARM) Aerosol Observing System (AOS; Jefferson, 2011; Dumka and Kaskaoutis, 2014; Dumka et Page 3 of $\mathbf{2 3}$ 
al., 2014b), which is the primary platform used for in-situ aerosol measurements at the surface. The number concentration of $\mathrm{CN}$ was measured by a butanol based Condensation Particle Counter (CPC; TSI Model 3010), which is a compact and rugged instrument that measures $\mathrm{N}_{\mathrm{CN}}$ in diameter range 0.01-3.0 $\mu \mathrm{m}$. The particles are allowed to grow large enough to be counted with a simple optical particle counter in the presence of butanol. The supersaturation ratio of butanol vapour in the condenser controls the minimum detectable particle size range of the counter. The instrument has a high signal-to-noise ratio that attains accurate detection of small particles. The upper concentration limit of the CPC is 10,000 particles per cubic centimetre.

$\mathrm{N}_{\mathrm{CCN}}$ were measured by a Droplet Measurement Technology (DMT) continuous flow single column CCN Counter [CCNC; Roberts and Nenes, 2005; Lance et al., 2006; Rose et al., 2008). It measures activated particle concentrations being converted to cloud droplets by condensation of water at a given S. According to the Köhler equation, the vapor pressure or S above an aqueous drop will vary with let drop surface tension and size and the solute concentration or chemical composition. During GVAX, the S of the CCN counter was stepped through 7 intervals with 5 minutes at each setting (Jefferson, 2011). The $S$ on the CCN datastream is calculated using a heat transfer and fluid dynamics flow model (Lance et al., 2006; Jefferson, 2010, 2011; and reference cited therein). The fluid dynamic flow model uses the calibrated temperatures, pressures, and flows within the instrument to calculate the $\mathrm{S}$. Changes in $\mathrm{S}$ are due to changes within the column thermal properties of the instrument. This CCN counter was calibrated at the beginning and end of the campaign (Jefferson, 2010, 2011; http://www.arm.gov/publications/tech_reports/handbooks/aos_handbook.pdf).

$\mathrm{N}_{\mathrm{CCN}}$ measurements were considered at 5-min intervals (1-min measurements averaged into $5 \mathrm{~min}$ ) for each $\mathrm{S}$ level, while $\mathrm{N}_{\mathrm{CN}}$ were measured continuously (1-min time interval, also averaged for $5 \mathrm{~min}$ ) by the CPC. This procedure leads to $\sim 41$ different set of measurements per day, which then were averaged on daily, monthly and seasonal basis. The $\mathrm{N}_{\mathrm{CN}}$ measurements used in the analysis are compared with those of $\mathrm{N}_{\mathrm{CCN}}$, since they were averaged at the same time intervals as the $\mathrm{N}_{\mathrm{CCN}}$ measurements for each $\mathrm{S}$ level.

In order to compare $\mathrm{N}_{\mathrm{CN}}$ and $\mathrm{N}_{\mathrm{CCN}}$ concentrations between $\mathrm{GH}$ and IGP regions, simultaneous measurements of $\mathrm{N}_{\mathrm{CN}}$ and $\mathrm{N}_{\mathrm{CCN}}$ were performed in Kanpur (independent of the GVAX campaign). Following methodology given by Lathem and Nenes (2011), a supersaturation depletion correction was applied to the Kanpur datasets, while the CCN counter has been calibrated before and after the deployment. Details of the measurement protocol at Kanpur, data analysis methods, instrument calibration, accuracy and errors are presented elsewhere (Patidar et al., 2012; Srivastava et al., 2013; Bhattu and Tripathi, 2014; Ram et al., 2014). 


\section{Results and Discussions}

\subsection{Temporal variation of $\mathrm{N}_{\mathrm{CN}}, \mathrm{N}_{\mathrm{CCN}}$ and Activation Ratio (AR)}

Figure 2 shows the daily-averaged values of $\mathrm{N}_{\mathrm{CCN}}, \mathrm{N}_{\mathrm{CN}}$ and $\mathrm{AR}$ at four $\mathrm{S}(0.17$ $0.22 \%, 0.31-0.33 \%, 0.46-0.48 \%$ and $0.75-0.78 \%$ ) levels at Nainital during the GVAX field campaign. The vertical solid line separates the $S$ levels for June to September 2011 (left) from those during November 2011 to March 2012 (right). Unfortunately, the $\mathrm{N}_{\mathrm{CN}}$ measurements were not available in October 2011 due to instrument technical problems. Significant temporal variations are seen during the entire period with daily-averaged $\mathrm{N}_{\mathrm{CN}}$ ranging from $684-5479 \mathrm{~cm}^{-3}$ (mean $\pm 1 \sigma$ of $\left.2630 \pm 969\right), 702-6555 \mathrm{~cm}^{-3}(2873 \pm 1162)$, $687-8183 \mathrm{~cm}^{-3}(3193 \pm 1467)$ and $282-9916 \mathrm{~cm}^{-3}(3588 \pm 1978)$ at $0.17-0.22 \%, 0.31-$ $0.33 \%, 0.46-0.48 \%$ and $0.75-0.78 \%$, respectively. The slight increase in $\mathrm{CN}$ at higher $\mathrm{S}$ is an artifact of the time-sampling differences between $\mathrm{CN}$ and $\mathrm{CCN}$ at different $\mathrm{S}$ and it would bias diurnal trends and spectral plots. The corresponding $\mathrm{N}_{\mathrm{CCN}}$ are on the order of $9-2180 \mathrm{~cm}^{-}$ ${ }^{3}$ (mean $\pm 1 \sigma$ of $\left.800 \pm 437\right), 24-3649 \mathrm{~cm}^{-3}(1421 \pm 728), 44-5411 \mathrm{~cm}^{-3}(1844 \pm 973)$ and $97-$ $6414 \mathrm{~cm}^{-3}$ (2138 \pm 1260$)$, respectively, which are typical for the GH region (Gajananda et al., 2005; Komppula et al. 2009; Sellegri et al. 2010; Moorthy et al., 2011; Hyvärinen et al., 2011); $\sigma$ corresponds to the standard deviation of the means over the whole measuring period. $\mathrm{N}_{\mathrm{CCN}}$ increases significantly with $\mathrm{S}$ implying numerous small particles. The monthly statistics of $\mathrm{N}_{\mathrm{CCN}}, \mathrm{N}_{\mathrm{CN}}$ and $\mathrm{AR}$ at $0.31-0.33 \% \mathrm{~S}$ are listed in Table 1. The large differences between maximum and minimum values $\left(\sim 3 \times 10^{3} \mathrm{~cm}^{-3}\right.$ for $\mathrm{N}_{\mathrm{CCN}}$ and $\sim 5 \times 10^{3}$ for $\left.\mathrm{N}_{\mathrm{CN}}\right)$ are indicative of the large variation of $\mathrm{CCN}$ and $\mathrm{CN}$ over the observation site. The highest monthly values of $\mathrm{N}_{\mathrm{CCN}}\left(2065 \pm 476 \mathrm{~cm}^{-3}\right)$ and $\mathrm{N}_{\mathrm{CN}}\left(4124 \pm 747 \mathrm{~cm}^{-3}\right)$ are observed in March, while the corresponding minimum $\left(684 \pm 396 \mathrm{~cm}^{-3}\right.$ and $\left.1606 \pm 453 \mathrm{~cm}^{-3}\right)$ in August. The minimum $\mathrm{N}_{\mathrm{CN}}$ monthly-mean value is slightly higher than that reported at Hanle, a highaltitude (5000 m amsl) station in the northwestern arid trans-Himalayan region. The $\mathrm{N}_{\mathrm{CN}}$ at Hanle during August to November 2009 varied between 80 and $8000 \mathrm{~cm}^{-3}$, with median and mean values of $\sim 950 \mathrm{~cm}^{-3}$ and $1150 \pm 500 \mathrm{~cm}^{-3}$ (Moorthy et al., 2011). This suggests that the Nainital site is under the influence of increased loading of mostly transported aerosol plumes from the IGP, which cannot cross the mountainous range and affect Hanle located in the lee (northern) slopes of the Himalayas.

The $\mathrm{N}_{\mathrm{CN}}$ values are somewhat comparable to those reported for another high altitude (2180 m amsl) site at Mukteshwar (3108 \pm 1570; $4010 \pm 1965 ; 3195 \pm 2683$ and $2124 \pm 1234$ $\mathrm{cm}^{-3}$, respectively for the years 2006, 2007, 2008 and 2009, Komppula et al., 2009) and about an order of magnitude lower than those $\left(25860 \pm 11707 \mathrm{~cm}^{-3}\right)$ observed over the polluted Gual Pahari site (243 m amsl in the IGP) during the year 2009 (Hyvärinen et al., 2011). Based on three years of continuous measurements in Mukteshwar (close to Nainital), Komppula et al. (2009) reported that the monthly averages of the total aerosol number 
concentration varied from $\sim 5700 \mathrm{~cm}^{-3}$ to $\sim 1200 \mathrm{~cm}^{-3}$ from pre-monsoon to monsoon. Measurements at the high altitude $(5079 \mathrm{~m}$ amsl) Nepal Climate Observatory-Pyramid, (Sellegri et al., 2010) have shown annual average aerosol number concentration on the order of $860 \pm 55 \mathrm{~cm}^{-3}$, exhibiting a strong seasonal variation with pre-monsoon and post-monsoon high $\left(\sim 1500 \mathrm{~cm}^{-3}\right.$ and $\left.1300 \mathrm{~cm}^{-3}\right)$ and monsoon low $\left(\sim 450 \mathrm{~cm}^{-3}\right)$. Since, the Pyramid is a remote site in the Everest area, the observed aerosol is mostly transported from the Indian polluted regions, while the annual pattern of $\mathrm{N}_{\mathrm{CN}}$ is a combination of the IGP aerosol variability and boundary-layer dynamics (Sellegri et al. 2010). On the other hand, airborne studies have shown significant vertical heterogeneity in $\mathrm{N}_{\mathrm{CN}}$ over the $\mathrm{GH}$ region, influenced by local emissions (mostly within the boundary layer), long-range transport (mostly at higher altitudes) and changes in mixing height (Dipu et al., 2013; Padmakumari et al., 2013; Srivastava et al., 2013). Airborne profiles during the CAIPEEX campaign in May 2009 have shown surface concentrations of $1100-1500 \mathrm{~cm}^{-3}$ and $800-1600 \mathrm{~cm}^{-3}$ at higher elevations (between 2 and $4 \mathrm{~km}$ ) over Pune, while the respective concentrations over Pathankot (a site in the GH region) were in the range of $1300-2800 \mathrm{~cm}^{-3}$ at the surface and $2500-6800 \mathrm{~cm}^{-3}$ at higher altitudes (between 2 and $4 \mathrm{~km}$ ) (Padmakumari et al., 2013). The higher $\mathrm{N}_{\mathrm{CN}}$ over the GH region is attributed to the influence of dust plumes from the Thar Desert and southwest Asia that also affect Nainital during the pre-monsoon season. The aerosol profiles revealed a nearly homogeneous vertical layer up to 3-4 km with concentrations of $\sim 800-1700 \mathrm{~cm}^{-3}$ and a decrease afterwards over Bareilly site in the IGP, just south of Nainital (Padmakumari et al., 2013). Using long-term (January 1996 to December 2003) analysis, Gajananda et al. (2005) have studied the aerosol number concentration at three altitude levels (1150,2050 and 2530 $\mathrm{m}$ amsl) in the northwestern Indian Himalayas reporting mean concentrations ranging from 4352 to $1392 \mathrm{~cm}^{-3}$ from the lowest to highest level, respectively. The above comparisons, as well as the comparison between Nainital and Kanpur (see section 3.7), reveal that the observing site is located at an intermediate zone between the polluted IGP and the mostly clean Himalayan range.

The $\mathrm{N}_{\mathrm{CCN}}$ is much lower during the monsoon months because of high precipitation and washout of the suspended particles. Similar annual variation (winter high and monsoon low) was found in Kanpur (Patidar et al., 2012), but with much higher $\mathrm{N}_{\mathrm{CCN}}$ values compared to Nainital. Based on aircraft measurements over Kanpur, Srivastava et al. (2013) reported high values of $\mathrm{N}_{\mathrm{CCN}}$ at $\mathrm{S}=0.84 \%$, such as $5293 \pm 978 \mathrm{~cm}^{-3}$ and $4431 \pm 1552 \mathrm{~cm}^{-3}$ on $2^{\text {nd }}$ July 2009 (at 10:35-12:25 and 14:15-15:15 hours local time, respectively). High mean values [3523 (0.81), $4572(0.64)$ and $2361(0.36)]$ of $\mathrm{N}_{\mathrm{CCN}}$ at $\mathrm{S}=0.3 \%$ were also reported for March, May-June and August, respectively over Kanpur (Bhattu and Tripathi, 2014); the values in parenthesis are the $\mathrm{AR}$ for the respective periods. 

mean values (Fig. 2), ranging from 0.01 to 0.67 (mean of $0.32 \pm 0.13$ ), 0.03 to 0.77 (0.51 \pm $0.13), 0.06$ to $0.78(0.58 \pm 0.12)$ and 0.03 to $0.80(0.60 \pm 0.14)$ at $0.17-0.22 \%, 0.31-0.33 \%$, $0.46-0.48 \%$ and $0.75-0.78 \% \mathrm{~S}$ levels, respectively. An AR value close to 1 indicates the presence of aged background aerosol (Andreae and Rosenfeld, 2008), while over the observational site the monthly-mean values are much lower than 1 at $0.31-0.33 \% \mathrm{~S}$ level (Table 1). The highest AR values during November are associated with biomass burning in northwestern India and aged transported aerosol plumes mixed with other organic or inorganic particles that are more hygroscopic (Lee et al., 2010). On the other hand, the observational site is above the planetary boundary layer in winter and, therefore, the aged free tropospheric aerosols may also play a role in the high AR values in that season (Venzac et al., 2009).

The mean values of $\mathrm{N}_{\mathrm{CN}}$ and $\mathrm{N}_{\mathrm{CCN}}$ observed at Nainital are higher than those reported during the Indian Ocean Experiment (Hudson and Yum, 2002) and lower than those found over the Korean Peninsula (Yum et al., 2005, 2007). During the Indian Ocean Experiment, Hudson and Yum (2002) found average values of $1808 \pm 41 \mathrm{~cm}^{-3}, 1190 \pm 128 \mathrm{~cm}^{-3}$ and 0.66 for $\mathrm{N}_{\mathrm{CN}}, \mathrm{N}_{\mathrm{CCN}}$ and $\mathrm{AR}$, respectively, at $1.0 \% \mathrm{~S}$. Very high values of $\mathrm{N}_{\mathrm{CN}}\left(6444 \pm 2732 \mathrm{~cm}^{-3}\right.$, $4644 \pm 2454 \mathrm{~cm}^{-3}$ and $\left.9804 \pm 4142 \mathrm{~cm}^{-3}\right)$ and $\mathrm{N}_{\mathrm{CCN}}\left(3445 \pm 1158 \mathrm{~cm}^{-3}, 2475 \pm 955 \mathrm{~cm}^{-3}\right.$ and $3178 \pm 1269 \mathrm{~cm}^{-3}$ ) at $0.49 \% \mathrm{~S}$ during August, September and October, respectively are reported at Shouxian, a polluted site in China (Liu et al., 2011). Aircraft measurements over Nainital on $29^{\text {th }}$ June 2009, revealed average values of $1363 \pm 327 \mathrm{~cm}^{-3}$ and 18,292 \pm 3770 $\mathrm{cm}^{-3}(0.84 \% \mathrm{~S})$ for $\mathrm{CCN}$ and $\mathrm{CN}$, respectively at the altitude range 518-5486 m (Srivastava et al., 2013). Recently, Konwar et al. (2012) reported $N_{C C N}$ of 1153-2470 $\mathrm{cm}^{-3}$ (for the northeastern part of India on $30^{\text {th }}$ August and $4^{\text {th }}-6^{\text {th }}$ September 2009) and $3361-10,635 \mathrm{~cm}^{-3}$ (for extremely polluted conditions in the IGP on $14^{\text {th }}-25^{\text {th }}$ August 2009) at $0.4 \% \mathrm{~S}$ during the CAIPEEX campaign. Shrestha et al. (2013) have studied the CCN properties over the central Nepal region (Besisahar) and reported mean $\mathrm{N}_{\mathrm{CCN}}$ of $435 \pm 98 \mathrm{~cm}^{-3}$ and $750 \pm 50 \mathrm{~cm}^{-3}$, during clean and hazy/polluted skies, respectively at $\mathrm{S}$ ranging from $0.35 \%$ to $0.45 \% ; \mathrm{N}_{\mathrm{CCN}}$ at another site (Dhulikhel) in Nepal was found to be $700 \mathrm{~cm}^{-3}$ at $\mathrm{S}=0.3 \%$. Table 2 summarises the values of $\mathrm{N}_{\mathrm{CCN}}, \mathrm{N}_{\mathrm{CN}}$ and $\mathrm{AR}$ obtained at Nainital (GVAX campaign) with those measured over high altitude sites over the globe. Asmi et al. (2012) have reported similar value of $\mathrm{N}_{\mathrm{CCN}}$ at Puy-de-Dome during summer $\left(200-2000 \mathrm{~cm}^{-3}\right)$ and winter $\left(50-3000 \mathrm{~cm}^{-3}\right)$ with $\mathrm{N}_{\mathrm{CN}}$ up to $10,000 \mathrm{~cm}^{-3}$. The AR (at $0.24 \% \mathrm{~S}$ ) ranges between 0.2 and 0.7 at Puy de Dome, which is comparable to that at Nainital. The $\mathrm{N}_{\mathrm{CN}}$ and $\mathrm{N}_{\mathrm{CCN}}$ at Mt. Sonnblick (Hitzenberger et al., 1999), Storm Peak Laboratory (Friedman et al., 2013) and Jungfraujoch (Jurănyi et al, 2010) sources like IGP. 


\subsection{Diurnal Variation}

The mean diurnal variations of $\mathrm{N}_{\mathrm{CCN}}, \mathrm{N}_{\mathrm{CN}}$ and $\mathrm{AR}$ at $0.31-0.33 \% \mathrm{~S}$ for characteristic months of each season are shown in Fig. 3a-c, respectively. A pronounced diurnal variation of $\mathrm{N}_{\mathrm{CCN}}$ and $\mathrm{N}_{\mathrm{CN}}$ is observed in November, December and March with prominent afternoon peaks, whereas the diurnal pattern is smooth and nearly vanished in June. During November to March, $\mathrm{N}_{\mathrm{CCN}}$ and $\mathrm{N}_{\mathrm{CN}}$ gradually increase from 08:00 until 15:00-18:00 hours to peak values, and then decrease to nighttime minima. Increased $\mathrm{N}_{\mathrm{CN}}$ and $\mathrm{N}_{\mathrm{CCN}}$ and larger variability around noon to early afternoon could be due to nucleation events and new particle formation (Moorthy et al., 2011).

Diurnal patterns for $A R$ are opposite those of $\mathrm{N}_{\mathrm{CCN}}$ and $\mathrm{N}_{\mathrm{CN}}$, with lower values during noon and late afternoon hours and larger values in the morning. The AR diurnal patterns are similar for the months of November and March, while the AR values are much lower in June. Diurnal variations are influenced by the planetary boundary layer dynamics and the mountain-valley winds. The role of mountain-valley breeze (upslope valley winds and downslope mountain winds during daytime and nighttime, respectively) and topography in diurnal variations of near-surface aerosol concentrations and trace gases at high-altitude sites has been well documented (Nishita et al., 2007; Panday and Prinn, 2009; Panday et al., 2009; Shrestha et al., 2010; Dumka et al., 2010; Sellegri et al. 2010; Moorthy et al., 2011; Sarangi et al., 2014). The upslope winds bring relatively polluted air masses from the IGP to the mountain slopes and play an important role in diurnal variations of aerosol over the $\mathrm{GH}$ region (Kleissl et al., 2007; Raatikainen et al., 2014). Diurnal patterns of $\mathrm{N}_{\mathrm{CCN}}$ and $\mathrm{N}_{\mathrm{CN}}$ are similar to the diurnal variations of the near surface aerosol and black carbon mass concentrations at Nainital (Pant et al., 2006; Dumka et al., 2010) due to uplift of pollutants from the IGP (Raatikainen et al., 2014). In contrast, the diurnal variation of $\mathrm{N}_{\mathrm{CCN}}$ in Kanpur (Patidar et al., 2012) presents a prominent peak in the morning ( 08:00 hours) and a secondary one in the evening (20:00 hours), closely following the diurnal variation of local aerosol emissions and mixing height dynamics (Tripathi et al., 2005). It is, therefore, concluded that both $\mathrm{N}_{\mathrm{CCN}}$ and $\mathrm{N}_{\mathrm{CN}}$ are strongly driven by daily aerosol and pollutant variations, of which surface heating, boundary-layer dynamics and long-range transport play a prominent role (Dumka et al., 2013).

\subsection{Variations with meteorological parameters}

It is well known that $\mathrm{N}_{\mathrm{CCN}}(\mathrm{S})$ (CCN spectra) depends on aerosol physico-chemical properties, meteorological conditions, and transport processes (Elminir, 2005; Cheng et al., 2008). Therefore, meteorological parameters, such as ambient temperature, surface wind speed and direction, measured by ARM mobile Facility surface meteorology station at $1 \mathrm{~min}$ intervals, are correlated with $\mathrm{N}_{\mathrm{CCN}}, \mathrm{N}_{\mathrm{CN}}$ and $\mathrm{AR}$ during the campaign. The analysis did not reveal a significant correlation of $\mathrm{N}_{\mathrm{CCN}}, \mathrm{N}_{\mathrm{CN}}$ and $\mathrm{AR}$ with ambient temperature over the site, Page $\mathbf{8}$ of 23 
even during periods without seasonal variations in temperature, i.e. noon-to-early afternoon hours during the hot season and/or evening/night hours during the cold period. Therefore, the analysis is limited to possible association with wind speed and direction.

The seasonal wind rose diagram is shown in Fig. 4 along with the seasonal distribution of $\mathrm{N}_{\mathrm{CN}}$ (Fig. 5), $\mathrm{N}_{\mathrm{CCN}}$ (Fig. 6) and AR (Fig. 7) at 0.31-0.33\% S. The bivariate plots (Openair software; Carslaw and Ropkins, 2012) could help to better visualize and denote wind direction and air-mass origin (see section 3.4), while the colour in the plots represents the magnitude of wind speed, $\mathrm{N}_{\mathrm{CN}}, \mathrm{N}_{\mathrm{CCN}}$ and $\mathrm{AR}$. All year round, the winds were mostly from the northwest and southeast directions, with speed less than $5 \mathrm{~m} \mathrm{~s}^{-1}$, indicating that the source of near-surface aerosols is related to local emissions and long-range transport, with the second mechanism dominating after examination of the diurnal patterns (Fig. 3). The southeasterlies clearly dominate during the monsoon and northwesterlies dominate during winter, while the two transition seasons have both wind directions (Fig. 4). The seasonallychanged wind directions significantly affect aerosol properties, $\mathrm{N}_{\mathrm{CCN}}$ and $\mathrm{N}_{\mathrm{CN}}$ due to longrange transported aerosols. The sensitivity of $\mathrm{N}_{\mathrm{CN}}$ and $\mathrm{N}_{\mathrm{CCN}}$ to wind direction is more pronounced in March, while it is lower during monsoon, suggesting that the rainy washout in this season reduces the influence of long-range aerosol transport over the $\mathrm{GH}$ region. $\mathrm{N}_{\mathrm{CN}}$ (Fig. 5) seems to be larger from southern and southwestern directions during winter revealing the influence of IGP, while $\mathrm{N}_{\mathrm{CCN}}$ (Fig. 6) follows a similar pattern in all seasons. In contrast, AR (Fig. 7) seems to be somewhat lower for southern directions during all seasons. This is more pronounced in winter, while in monsoon air masses from south could be associated with high AR values. Seasonal variations of $\mathrm{N}_{\mathrm{CCN}}, \mathrm{N}_{\mathrm{CN}}$ and $\mathrm{AR}$ at $0.31-0.33 \% \mathrm{~S}$ in the four wind quadrants are summarized in Fig. 8, respectively. $\mathrm{N}_{\mathrm{CCN}}$ and $\mathrm{N}_{\mathrm{CN}}$ increase from monsoon toward pre-monsoon (March) in all four quadrants whereas AR increases from monsoon to post-monsoon and then remains almost constant for winter and March. The higher values of $\mathrm{N}_{\mathrm{CCN}}$ and $\mathrm{N}_{\mathrm{CN}}$ in $180^{\circ}-270^{\circ}$ and $270^{\circ}-360^{\circ}$ quadrants are due to the transport of aerosols from the IGP and west Asian regions, while the AR values are not strongly influenced by the wind direction. However, the sectors that are associated with high $\mathrm{N}_{\mathrm{CCN}}$ and $\mathrm{N}_{\mathrm{CN}}$ seem to have lower AR values, suggesting more hydrophobic aerosols.

\subsection{Source analysis and long-range transport}

In order to study aerosol source identification and the effects of long-range transport over the observation site, the 5-days isentropic air mass back trajectories at $500 \mathrm{~m}$ above ground level were analysed for $6(00 ; 06 ; 12$ and 18) hours singular. The HYSPLIT model (Draxler et al., 2012; http://ready.arl.noaa.gov/HYSPLIT.php) was used together with the Global Data Assimilation System (GDAS1) meteorological database as input to calculate the air mass back trajectories in each season (Fig. 9). The trajectories are colour-coded according 
to the altitude attained by the air masses along the pathway before arriving at the observation site.

During the winter season, the wind pattern over the observation site is mostly northwesterly (Fig. 4a), while during the pre- and post-monsoon seasons the air masses circulate around the observation site with a clear western preference during pre-monsoon. The high values of $\mathrm{N}_{\mathrm{CN}}$ and $\mathrm{N}_{\mathrm{CCN}}$ during winter are due to the arrival of air masses from the Indian subcontinent and Southwest Asia. It is interesting to note that the western air masses travel at higher altitudes (above $3 \mathrm{~km}$ ), lowering in height, usually below $1 \mathrm{~km}$, while approaching the observation site. The lower values of $\mathrm{N}_{\mathrm{CN}}$ and $\mathrm{N}_{\mathrm{CCN}}$ during the Indian summer monsoon are mostly due to rainfall washout and not so much due to clean marine air masses from the Bay of Bengal (Hyvärinen et al., 2011). The highest $\mathrm{N}_{\mathrm{CCN}}$ and $\mathrm{N}_{\mathrm{CN}}$ during the pre-monsoon season (Fig. 8) are mostly associated with air-masses coming from the arid west Asian countries (e.g. Pakistan, Afghanistan, Iran) and passing through the Thar Desert, while during post-monsoon the contribution of biomass-burning aerosols from IGP increases (Kaskaoutis et al., 2014). The analysis shows that the air masses are mostly within the atmospheric boundary layer $(<500-1000 \mathrm{~m})$ near the observation site and progressively increase in altitude at greater distances, either towards the west (winter/pre-monsoon) or towards the east-southeast (monsoon). This suggests that boundary layer dynamics over the polluted IGP play a prominent role in long-range transport and air mass uplift (Dumka et al., 2014b).

The mixing-height was also obtained from the hourly intervals of the HYSPLIT outputs and estimated using the Turbulent Kinetic Energy (TKE) profile method (Draxler et al., 2012), in which the mixing height is assigned to the height at which TKE either decreases by a factor of two or to a value less than $0.21\left(\mathrm{~m}^{2} / \mathrm{s}^{2}\right)$. The monthly statistics of the mixing height at Nainital are given in Table 1 and the seasonal-mean diurnal variations are shown in Fig. 10. The mixing height is lowest during December $(271.5 \pm 367.7 \mathrm{~m}$ ranging between 12.8 and $1043.6 \mathrm{~m})$ and highest during June $(672.6 \pm 553.6 \mathrm{~m}$ ranging between 93.9 and $1546.9 \mathrm{~m}$ ) following the thermal heating of the surface. Furthermore, its diurnal variation is very strong, especially in March, with high values $(\sim 2000 \mathrm{~m})$ during noon and just a few meters during nighttime (Fig. 10). The diurnal pattern weakens in the other seasons; however, it is characteristic of the boundary-layer dynamics trapping the aerosols near the ground during the cold period of the year and during nighttime, and favouring their dilution (uplift to higher altitudes) during noontime to afternoon. Opposite to that expected from the boundarylayer dynamics, the diurnal variation of $\mathrm{N}_{\mathrm{CCN}}$ and $\mathrm{N}_{\mathrm{CN}}$ revealed higher values during noon-toearly afternoon hours (Fig. 3) suggesting dominance of long-range transport of aerosols from Ganges Basin and west Asia favoured in their uplift by the larger mixing height. In this respect, Prabha et al. (2012) revealed the removal of pollution from the IGP to higher 
atmospheric levels in association with dynamically forced updrafts. Their results showed that the valley pollution could be uplifted to heights above the haze layer, favoured by the buoyancy that is generated due to thermal heating of the surface during noon-to-early afternoon hours. It should be noted that the monthly-mean diurnal variations (Fig. 3), coincide well with the respective seasonal variations, thus allowing an association between variations in $\mathrm{N}_{\mathrm{CN}}, \mathrm{N}_{\mathrm{CCN}}$ and boundary-layer height.

\subsection{Relation of $\mathrm{N}_{\mathrm{CCN}}$ with $\mathrm{S}$}

In this section, we examine the monthly-mean $\mathrm{N}_{\mathrm{CCN}}$ as a function of $\mathrm{S}$ and determine the parameters for the "CCN spectrum" by following Jefferson (2010):

$\mathrm{N}_{\mathrm{CCN}}(\mathrm{S})=c \mathrm{~S}^{k}$

where $\mathrm{S}$ is the super-saturation in percent, $c$ and $k$ are constant terms that relate to the particle number concentration and chemical composition. Figure 11 shows the monthly and seasonal (winter and monsoon) means of $\mathrm{N}_{\mathrm{CCN}}$ as a function of $\mathrm{S}$, while the $c$ and $k$ parameters were estimated for different ranges of $\mathrm{S}$ (Table 3) using the least-square fit method in log-log scale (Khvorostyanov and Curry, 2006; Jefferson, 2010 and reference therein). The results show that the increasing trends of $\mathrm{N}_{\mathrm{CCN}}$ with $\mathrm{S}$ are less steep during June to September (monsoon) compared to November - March (considered as winter), thus associated with lower $k$ values. During monsoon, the variation of $\mathrm{N}_{\mathrm{CCN}}$ is constant above $\mathrm{S}=$ $0.45 \%$, suggesting no CCN with critical $\mathrm{S}\left(\mathrm{S}_{\mathrm{c}}\right)>0.45 \%$, whereas $\mathrm{N}_{\mathrm{CCN}}$ increases from 1500 to 2500 during winter, suggesting more particles with $S_{c}>0.4 \%$. The difference in increasing rates between the two seasons reveals differences in particle composition and size. The $c$ and $k$ values $(0.10 / 0.17-0.75 / 0.78 \mathrm{~S})$ range from $1092 \pm 47 \mathrm{~cm}^{-3}$ (August) to $5065 \pm 755 \mathrm{~cm}^{-3}$ (March) and $0.31 \pm 0.13$ (June) to $1.24 \pm 0.12$ (March), respectively (Table 3) and are, in general, within the range of values reported for continental aerosols (Seinfeld and Pandis, 1998), except for December to March, where the $c$ values are higher suggesting more turbid atmospheres approaching urban conditions. The $c$ value reflects the $\mathrm{CCN}$ concentration, while $k$ shows the increase in $\mathrm{CCN}$ with $\mathrm{S}$, which shows a decreasing tendency for increasing S (lower $k$ values for larger S) (Hudson and Noble, 2014). This is mostly observed during the winter period, while during monsoon $k$ does not present a clear tendency with $\mathrm{S}$. The $k$ values obtained at Nainital are higher than the value $(k=0.15)$ reported by Engelhart et al. (2008) for aged monoterpene secondary organic aerosols and Bhattu and Tripathi (2014) at Kanpur $(0.16 \pm 0.08)$ for dominance of organic species.

\subsection{Correlation between $\mathbf{N}_{\mathrm{CCN}}$ and $\mathbf{N}_{\mathrm{CN}}$}

In this section, we further investigate the relationship between $\mathrm{N}_{\mathrm{CN}}$ and $\mathrm{N}_{\mathrm{CCN}}$ and $\mathrm{AR}$. Figure 12 represent the scatter plots of $\mathrm{N}_{\mathrm{CCN}}$ and $\mathrm{AR}$ as a function of $\mathrm{N}_{\mathrm{CN}}$ (integrated at every $500 \mathrm{~cm}^{-3}$ bin) during the whole measurement period at three $\mathrm{S}$, i.e. $0.31-0.33 \%, 0.46-0.48 \%$ 
and $0.75-0.78 \%$. The vertical bars represent the standard deviations about the means, while the dotted lines are the fitted power-law functions $\left[\mathrm{Y}=\mathrm{A}\left(\mathrm{x}-\mathrm{x}_{\mathrm{c}}\right)^{\mathrm{P}}\right.$ for $\mathrm{N}_{\mathrm{CCN}} \mathrm{vs} \mathrm{N}_{\mathrm{CN}}$ and $\mathrm{Y}=\mathrm{a}+$ $\mathrm{bx}^{\mathrm{c}}$ for $\mathrm{AR}$ vs $\mathrm{N}_{\mathrm{CN}}$ ] for each $\mathrm{S}$. The large standard deviations indicate that there is large variability in $\mathrm{N}_{\mathrm{CCN}}$ for each $\mathrm{N}_{\mathrm{CN}}$ interval, suggesting that it is difficult to estimate $\mathrm{N}_{\mathrm{CCN}}$ over the GH region without having information about the chemical composition of aerosols (Yum et al., 2007). Figure 12a shows that for all $S N_{C C N}$ increases with increasing $N_{C N}$, initially with a very high rate, which decrease above $5-6 \times 10^{3} \mathrm{~cm}^{-3} \mathrm{~N}_{\mathrm{CN}}$. The AR shows decreasing trend with $\mathrm{N}_{\mathrm{CN}}$, which becomes greater as $\mathrm{N}_{\mathrm{CN}}$ increases indicating that more turbid atmospheres are less CCN active. Similar results are also reported over Gosan, Korea for polluted air masses during the Atmospheric Brown Clouds-East Asian Regional Experiment (Yum et al., 2007).

Figure 13 presents the $\mathrm{N}_{\mathrm{CCN}}$ variation as a function of $\mathrm{N}_{\mathrm{CN}}$, using raw data on seasonal basis at two S levels 0.31-0.33 (black color) and 0.75-0.78 (red color). Although the correlations appear to be similar in all seasons (i.e., increasing trend of $\mathrm{N}_{\mathrm{CCN}}$ with $\mathrm{N}_{\mathrm{CN}}$ ), differences are observed in the respective regression slopes. Thus, during winter, premonsoon and monsoon, the regression slope between $\mathrm{N}_{\mathrm{CCN}}$ and $\mathrm{N}_{\mathrm{CN}}$ is about 0.37 , while in post-monsoon it is higher $(0.50)$ at $0.33 \% \mathrm{~S}$, suggesting more CCN. At $0.75-0.78 \% \mathrm{~S}$ level, the slopes for post-monsoon, winter and pre-monsoon are similar $(\sim 0.63)$, while during monsoon the slope is much lower (0.45), resulting in small differences in AR between the two $\mathrm{S}$ levels. This indicates that $\mathrm{N}_{\mathrm{CCN}}$ is either a weak (monsoon) or strong function of $\mathrm{S}$. The results also reveal that the differences in $\mathrm{N}_{\mathrm{CCN}}$ between the two $\mathrm{S}$ levels are much larger at high $\mathrm{CN}$ concentrations, suggesting that the larger aerosol loading needs higher $\mathrm{S}$ levels in order to be CCN. In contrast, for aerosol concentrations below $\sim 3 \times 10^{3} \mathrm{~cm}^{-3}, \mathrm{~N}_{\mathrm{CN}}$ is similar to $\mathrm{N}_{\mathrm{CCN}}$ (especially in monsoon), revealing that the vast majority of particles are CCN.

In synopsis, the results revealed that the ratio of $\mathrm{N}_{\mathrm{CCN}}$ to $\mathrm{N}_{\mathrm{CN}}$ or $\mathrm{AR}$ is seasonally dependent over Nainital indicating influence of distinct aerosol sources, transport pathways, rainfall and mixing processes. Furthermore, the contrasting features of the $\mathrm{N}_{\mathrm{CN}} \mathrm{vs}_{\mathrm{CCN}}$ as a function of $\mathrm{S}$ for monsoon and winter are examined in Fig. 14(a-e). The correlation coefficients and the slopes of the linear regressions increase with the $\mathrm{S}$ levels for both seasons, but the activation of $\mathrm{CN}$ to $\mathrm{CCN}$ is more efficient in winter (larger slopes) than in monsoon (Fig. 14a-e). Furthermore, the slopes of activation increase in a faster rate with $\mathrm{S}$ level in winter (from 0.18 at $0.17 \% \mathrm{~S}$ to 0.63 for $0.77 \% \mathrm{~S}$ ) compared to monsoon (from 0.21 at $0.17 \% \mathrm{~S}$ to 0.42 at $0.77 \% \mathrm{~S}$ ), suggesting larger increase in $\mathrm{AR}$ as a function of $\mathrm{S}$ in winter (Fig. 14). Measurements at Puy-de-Dome (Asmi et al., 2012) revealed higher slope of CCN vs $\mathrm{CN}$ during winter (slope $=0.47$ with $\mathrm{R}^{2}=0.80$ ) than monsoon (slope $=0.13$ with $\mathrm{R}^{2}=$ $0.15)$, results that are similar to those found at Nainital. 


\subsection{Comparison between Nainital and IGP-Kanpur site}

During the period June-August 2011, simultaneous measurements of $\mathrm{N}_{\mathrm{CCN}}$ and $\mathrm{N}_{\mathrm{CN}}$ were performed in Kanpur (independent from GVAX campaign). Figure 15a, b shows the daily variation of $\mathrm{N}_{\mathrm{CCN}}$ and $\mathrm{N}_{\mathrm{CN}}$, respectively at Kanpur and Nainital (box and whisker chart view), while the daily-mean AR values are shown in Fig. 15c. For all the graphs the $\mathrm{S}$ level at Kanpur is $0.2 \%$ and at Nainital $0.17 \%$. Considerable day-to-day variation is observed in the $\mathrm{N}_{\mathrm{CCN}}$ and $\mathrm{N}_{\mathrm{CN}}$ at both sites, which is much stronger in Kanpur due to higher rates of anthropogenic emissions that enhance the concentrations 3 to 4 times those observed at Nainital. The mean $\mathrm{N}_{\mathrm{CCN}}$ at Kanpur was found to be $2408 \pm 1030 \mathrm{~cm}^{-3}$ compared to $589 \pm$ $288 \mathrm{~cm}^{-3}$ at Nainital, while the $\mathrm{N}_{\mathrm{CN}}$ is $9862 \pm 4694 \mathrm{~cm}^{-3}$ and $2132 \pm 701 \mathrm{~cm}^{-3}$ at Kanpur and Nainital, respectively. On the other hand, on specific days (i.e. 24 June and 3 July, 2011) the $\mathrm{CCN}$ values at Kanpur and Nainital are comparable, but in the vast majority of the cases they exhibit significant differences in both $\mathrm{N}_{\mathrm{CCN}}$ and $\mathrm{N}_{\mathrm{CN}}$. Besides large differences in the $\mathrm{N}_{\mathrm{CCN}}$ and $\mathrm{N}_{\mathrm{CN}}$, the mean $\mathrm{AR}$ is comparable at both sites $(0.30 \pm 0.08$ at Kanpur and $0.28 \pm 0.15$ at Nainital), in spite of the deviations that are observed on certain days due to different aerosol composition, the influence of various sources and additional anthropogenic emissions at Kanpur (Ram et al., 2008, 2010; Kumar et al., 2014). The consistency in the AR values suggests similarities in the origin, characteristics and chemical composition of aerosols, supporting transport from the Ganges valley to the Himalayan foothills. The differences between the two locations for higher $\mathrm{S}$ levels $(0.31-0.4$ and $0.75-0.8)$ were found to be similar to those at $0.2 \% \mathrm{~S}$ and the results are summarized in Table 4. Based on two years of continuous measurements of $\mathrm{CCN}$ and $\mathrm{CN}$ at Kanpur, Patidar et al. (2012) reported significant inter and intra-seasonal variations, which could be due to varying local emissions, influence of long-range transport and different chemical composition. In synopsis, the $\mathrm{N}_{\mathrm{CCN}}$ and $\mathrm{N}_{\mathrm{CN}}$ over Kanpur are very high (about 3-4 times more) compared to those at Nainital, attributed to the turbid environment over the Ganges basin during the whole year (Kaskaoutis et al., 2013).

\section{Conclusions}

The time-series analysis of $\mathrm{N}_{\mathrm{CN}}, \mathrm{N}_{\mathrm{CCN}}$ and $\mathrm{AR}$ was presented in the framework of an intensive field campaign GVAX in the Gangetic - Himalayan region during June 2011 to March 2012. The measurements correspond to the Nainital site, located in Indian Himalayas (1958 m amsl) above the polluted Ganges basin. The main findings of the study are summarized as follows:

1. The CCN, CN and AR showed a pronounced monthly variation with high values during November to March and low during June to September. 
2. Strong-to-neutral diurnal variation of $\mathrm{N}_{\mathrm{CCN}}$ and $\mathrm{N}_{\mathrm{CN}}$ was observed during the winter-tosummer season, with afternoon maximums, while the diurnal variation of AR was in opposite phase (morning maximum and noon minimum). The lower AR during noontime suggests more non-CCN particles transported from IGP. The diurnal cycles were attributed to the evolution of the atmospheric boundary layer and the uplift of pollutants from the IGP during the afternoon.

3. Seasonally-changing meteorological conditions favouring transport of aerosols from different sources, along with boundary-layer dynamics and RH variations, seem to play an important role in $\mathrm{CCN}$ concentrations. The air-mass back trajectories revealed dominance of aerosol transport from northwestern India and the west Asian regions, especially during winter and pre-monsoon. In contrast, during summer monsoon the air masses were mostly of marine origin and, combined with the rainy washout over northern India, they were associated with lower aerosol concentrations.

4. The average values of $k$ obtained from the power law fit between $\mathrm{N}_{\mathrm{CCN}}$ and $\mathrm{S}$ were found to range between $0.31 \pm 0.13$ (June) and $1.24 \pm 0.12$ (March), while $k$ exhibited a decreasing trend with $\mathrm{S}$ during winter and was nearly constant in monsoon. Furthermore, the particles were found to have larger values of $k$ during winter, whereas in monsoon $\mathrm{N}_{\mathrm{CCN}}$ increases with $\mathrm{S}$ till $\sim 0.45 \% \mathrm{~S}$ and remains rather constant above it. $\mathrm{N}_{\mathrm{CCN}}$ increased significantly with increasing $\mathrm{N}_{\mathrm{CN}}$, but $\mathrm{AR}$ decreased with $\mathrm{N}_{\mathrm{CN}}$ at all $\mathrm{S}$ levels suggesting that the more turbid atmospheres do not favour CCN.

5. The $\mathrm{N}_{\mathrm{CCN}}$ and $\mathrm{N}_{\mathrm{CN}}$ values at Nainital were much lower (3-4 times) than those measured at Kanpur during the monsoon period. In contrast, the mean AR was found to be similar at the two sites suggesting aerosols of similar origin and characteristics, although on some days it exhibited significant differences.

\section{Acknowledgment}

We acknowledge U.S. Department of Energy Atmospheric Radiation Measurements Climate Research Facility for providing database (http://www.archive.arm.gov/) for this work. This study is carried out under GVAX (https://www.arm.gov/sites/amf/pgh/) project in collaboration among the DoE, IISc, SPL, ISRO and ARIES. We would like to thank all the participants in the campaign (scientists and technicians) for their keen interest, data collection and kind support. HYSPLIT transport and dispersion model data (NOAA ARL) are used from READY website (http://www.arl.noaa.gov/ready.html) for the back-trajectory analysis. The authors are thankful to Dr N. Ojha and Dr David Carslaw for the fruitful discussion during the airmass back trajectory analysis. The authors are thankful to the referee for insightful comments and valuable suggestions, which helped us significantly in improving the scientific quality of the manuscript.

\section{Page 14 of 23}




\section{References}

Andreae, M. O. and Rosenfeld, D., 2008. Aerosol-cloud-precipitation interactions Part 1, The nature and sources of cloud-active aerosols. Earth-Sci. Rev., 89, 13-41.

Andreae, M. O. et al., 2004. Smoking Rain Clouds over the Amazon. Science, 303, 13371342.

Asmi, E., Freney E., Hervo M., Picard D., Rose C., Colomb A., and Sellegri K., 2012. Aerosol cloud activation in summer and winter at puy-de-Dome high altitude site in France Atmos. Chem. Phys., 12, 11589-11607, doi: 10.5194/acp-12-11589-2012.

Bhattu, D., and Tripathi, S.N., 2014. Inter-seasonal variability in size-resolved CCN properties at Kanpur, India. Atmos. Environ., doi: 10.1016/j.atmosenv.2013.12.016.

Carslaw, D. C. and Ropkins, K. 2012. Openair-An R package for air quality data analysis. Environ. Model. Softw., 27-28, 52-61.

Chakravarty, Mukhopadhyay` K., Taraphdar P. S. 2011. Cloud microphysical properties as revealed by the CAIPEEX and satellite observations and evaluation of a cloud system resolving model simulation of contrasting large scale environments. J. Atmos. Sol. Terr. Phys., 73, 1790-1797.

Cheng, Y. F., Wiedensohler A., Eichler H. et al., 2008. Relative humidity dependence of aerosol optical properties and direct radiative forcing in the surface boundary layer at Xinken in Pearl River Delta of China: An observation based numerical study. Atmos. Environ., 42(25), 6373-6397.

Dey S., and Di Girolamo L, 2010. A climatology of aerosol optical and microphysical properties over the Indian Subcontinent from 9 years (2000-2008) of Multiangle Imaging SpectroRadiometer (MISR) data. J. Geophys. Res., 115, D15204, doi: 10.1029/2009JD013395.

Dey, S., and Di Girolamo L., 2011. A decade of change in aerosol properties over the Indian subcontinent. Geophys. Res. Lett., 38, L14811, doi: 10.1029/2011GL048153.

Dipu, S., Prabha Thara V., Pandithurai G., Dudhia J., Pfister G., Rajesh K., and Goswami B.N. 2013. Impact of elevated aerosol layer on the cloud macrophysical properties prior to monsoon onset. Atmos. Environ., 70, 454-467.

Draxler, R. et al., 2012., HYSPLIT4 user's guide, version 4, report, NOAA, Silver Spring, Md. [www.arl.noaa.gov/documents/reports/hysplit_user_guide.pdf].

Dumka, U. C., and Kaskaoutis D. G., 2014. In-situ measurements of aerosol properties and estimates of radiative forcing efficiency over Gangetic-Himalayan region during the GVAX field campaign, Atmos. Environ., 94, 96-105.

Dumka, U. C., Krishna Moorthy K., Satheesh S. K., Sagar Ram and Pant P., 2008. Short period modulations in aerosol optical depths over central Himalayas: Role of mesoscale processes. J. Appl. Meteorol. Climatol, 47, 1467-1475.

Dumka U.C., Krishna Moorthy K., Kumar Rajesh, Hegde P., Sagar Ram, Pant P., Singh Narendra and Babu S. Suresh 2010. Characteristics of aerosol black carbon mass concentration over a high altitude location in the Central Himalayas from multi-year measurements. Atmos. Res., 96, 510-521.

Dumka U.C., Krishna Moorthy K., Tripathi S. N., Hegde P. and Sagar Ram, 2011. Altitude variation of aerosol properties over the Himalayan range inferred from spatial measurements. J. Atmos. Sol-Terr. Phys., 73, 1747-1761.

Dumka U.C. Manchanda R. K., Sinha P. R., Sreenivasam S., Krishna Moorthy K. and Babu S. Suresh, 2013. Temporal variability and radiative impact of black carbon aerosol over tropical urban station Hyderabad. J. Atmos. Sol-Terr. Phys., 105-106, 81-90.

Dumka, U. C., Tripathi S. N., Misra A., Giles D. M., Eck T. F., Sagar R., and Holben B. N., 2014a. Latitudinal variation of aerosol properties from Indo-Gangetic Plain to central 
Himalayan foothills during TIGERZ campaign. J. Geophys. Res. Atmos., 119, doi: 10.1002/2013JD021040.

Dumka, U. C., Kaskaoutis D. G., Srivastava M. K., and Devara P. C. S., 2014b. Scattering and absorption properties of near-surface aerosol over Gangetic-Himalayan region: the role of boundary layer dynamics and long-range transport. Atmos. Chem. Phys. Discuss., 14, 21101-21148, doi: 10.5194/acpd-14-21101-2014.

Dusek, U., Frank G.P., Hildebrandt L., Curtius J., Schneider J., Walter S., Chand D., Drewnick F., Hings Jung S., Borrmann D.S., Andreae M.O., 2006. Size matters more than chemistry in controlling which particles can nucleate cloud droplets. Science, 312, 1375-1378.

Dutkiewicz, V., Sofia Alvi A., Ghauri Badar M., Choudhary M. Iqbal, Husain Liaquat, 2009. Black carbon aerosols in urban air in South Asia, Atmos. Environ., 43, 1737-1744.

Elminir H. K., 2005. Dependence of urban air pollutants on meteorology. Sci. Total Environ, 350(1-3), 225-237.

Engelhart, G. J., Asa-Awuku A., Nenes A. and Pandis S. N., 2008., CCN activity and droplet growth kinetics of fresh and aged monoterpene secondary organic aerosol. Atmos. Chem. Phys., 8, 3937-3949.

Fitzgerald, J. W. (1973), Dependence of the supersaturation spectrum of CCN on aerosol size distribution and composition, J. Atmos. Sci., 30, 628-634.

Friedman, B., Zelenyuk A., Beránek J., Kulkarni G., Pekour M., Hallar A. G., McCubbin I. B., Thornton J. A., and Cziczo D. J., 2013. Aerosol measurements at a high elevation site: composition, size, and cloud condensation nuclei activity. Atmos. Chem. Phys., 13, 11839-11851, doi: 10.5194/acp-13-11839-2013.

Gajananda, K., Kuniyal Jagdish C., Momin G.A., Rao P.S.P., Safai P.D., Tiwari S. and Ali K., 2005. Trend of atmospheric aerosols over the north western Himalayan region, India. Atmos. Environ., 39, 4817-4825.

Hitzenberger, R., Berner A., Giebl H., Kromp R., Larson S., Rouc A., Koch S.M., Puxbaum H., 1999. Contribution of carbonaceous material to cloud condensation nuclei concentrations in European background (Mt.Sonnblick) and urban (Vienna) aerosols. Atmos. Env. 33, 2647-2659.

Hudson, J. G., and Yum S. S., 2002. Cloud condensation nuclei spectra and polluted and clean clouds over the Indian Ocean. J. Geophys. Res., 107(D19), 8022, doi: 10.1029/2001JD000829.

Hudson, J.G., and Noble, S., 2014. CCN and vertical velocity influences on droplet concentrations and supersaturations in clean and polluted stratus clouds. J. Atmos. Sci., 71, 312-331.

Hyvärinen A. P., Raatikainen T., Komppula M., Mielonen T., Sundström A. M., Brus D., Panwar T. S., Hooda R. K., Sharma V. P., Leeuw G. de, and Lihavainen H., 2011. Effect of the summer monsoon on aerosols at two measurement stations in Northern India-Part 2: Physical and optical properties. Atmos. Chem. Phys., 11, 8283-8294, doi: 10.5194/acp-11-8283-2011.

Jaidevi, J., Tripathi S. N., Gupta Tarun, Singh B. N., Gopalakrishnan V. and Dey Sagnik, 2011. Observation-based 3-D view of aerosol radiative properties over Indian Continental Tropical Convergence Zone: Implications to regional climate. Tellus $B$, 63(5), 971-989.

Jefferson A., 2010. Empirical estimates of CCN from aerosol optical properties at four remote sites. Atmos. Chem. Phys., 10, 6855-6861, doi: 10.5194/acp-10-6855-2010. 
Jefferson, A., 2011. Aerosol Observing System (AOS) Handbook, U. S. Department of Energy, DOE/SC- ARM/TR-014, available at http://www.arm.gov/publications/tech_reports/handbooks/aos_handbook.pdf.

Jethva, H., Satheesh S. K., and Srinivasan J., 2005. Seasonal variability of aerosols over the Indo-Gangetic basin. J. Geophys. Res., 110, D21204, doi: 10.1029/2005JD005938.

Junge, C.E., McLaren, E., 1971. Relationship of cloud nuclei spectra to aerosol size distribution and composition. J. Atmos. Sci. 28, 382-390.

Jurănyi, Z, Gysel M., Weingartner E., DeCarlo P.F., Kammermann L., and Baltensperger U., 2010. Measured and modelled cloud condensation nuclei number concentration at the high alpine site Jungfraujoch. Atmos. Chem. Phys., 10, 7891-7906, doi: 10.5194/acp-107891-2010.

Kaskaoutis D. G., Singh Ramesh P, Gautam Ritesh, Sharma Manish, Kosmopoulos P G and Tripathi S N (2012), Variability and trends of aerosol properties over Kanpur, northern India using AERONET data (2001-10). Environ. Res. Lett. 7, doi:10.1088/17489326/7/2/024003.

Kaskaoutis, D.G., S. Kumar, D. Sharma, R.P. Singh, S.K. Kharol, M. Sharma, A.K. Singh, S. Singh, A. Singh, D. Singh, 2014. Effects of crop residue burning on aerosol properties, plume characteristics and long-range transport over northern India. J. Geophys. Res., (in press), doi: 10.1002/2013JD021357

Kaskaoutis, D.G., Sinha P.R., Vinoj V., Kosmopoulos P.G., Tripathi S.N., Misra Amit, Sharma M., Singh R.P., 2013. Aerosol properties and radiative forcing over Kanpur during severe aerosol loading conditions. Atmos. Environ., 79, 7-19.

Kaufman, Y. J., Tanre, D., and Boucher, O., 2002. A satellite view of aerosols in the climate system. Nature, 419, 215-223, doi: 10.1038/nature01091.

Khvorostyanov, V. I., and Curry J. A., 2006. Aerosol size spectra and CCN activity spectra: Reconciling the lognormal, algebraic, and power laws. J. Geophys. Res., 111, D12202, doi: 10.1029/2005JD006532.

Kleissl, J. Honrath, R. E., Dziobak M. P., Tanner D., Martin M. Val, Owen R. C., and Helmig D., 2007. Occurrence of upslope flows at the Pico mountaintop observatory: A case study of orographic flows on a small, volcanic island. J. Geophys Res, 112, D10S35, doi: 10.1029/2006JD007565.

Komppula, M., Lihavainen H., Hyvärinen A. P., Kerminen V. M., Panwar T. S., Sharma V. P., and Viisanen Y., 2009. Physical properties of aerosol particles at a Himalayan background site in India. J. Geophys. Res., 114, D12202, doi: 10.1029/2008JD011007.

Konwar, M., Maheskumar R. S., Kulkarni J. R., Freud E., Goswami B. N., and Rosenfeld D., 2012. Aerosol control on depth of warm rain in convective clouds. J. Geophys. Res., 117, D13204, doi: 10.1029/2012JD017585.

Kumar, R., Barth M.C., Pfister G.G., Naja M., and Brasseur G.P., 2014. WRF-Chem simulations of a typical pre-monsoon dust storm in northern India: influences on aerosol optical properties and radiation budget. Atmos. Chem. Phys., 14, 2431-2446.

Lance, S., Medina, J., Smith, J. N., and Nenes, A., 2006. Mapping the Operation of the DMT Continuous Flow CCN Counter. Atmos. Sci. Tech., 40, 242-254.

Lance, S., Nenes, A., Claudio, M., Dubey, M.K., Gates, H., Varutbangkul, V., Rissman, T.A., Murphy, S.M., Sorooshian, A., Flagan, R.C., Seinfeld, J.H., Feingold, G., Jonsson, H. H., 2009. Cloud condensation nuclei activity, closure, and droplet growth kinetics of Houston aerosol during the Gulf of Mexico Atmospheric Composition and Climate Study (GoMACCS). J. Geophys. Res. 114, D00F15, doi: 10.1029/2008JD011699. 
Lathem, T.L., Nenes, A., 2011. Water vapor depletion in the DMT continuous-flow CCN chamber: effects on supersaturation and droplet growth. Aerosol Sci. Technol. 45, 604615.

Lawrence, M. G., 2011. Atmospheric science: Asia under a high-level brown cloud. Nat. Geosci, 4, 30 352-353.

Lawrence, M. G., and Lelieveld J., 2010. Atmospheric pollutant outflow from southern Asia: A review. Atmos. Chem. Phys., 10, 11017-11096.

Lee, S., Ghim Y. S., Kim S.W., Yoon S.C., 2010. Effect of biomass burning and regional background aerosols on CCN activity derived from airborne in-situ measurements, Atmos. Env. 44, 5227-5236.

Liu, J., Zheng Y., Li Z., and Cribb M., 2011. Analysis of cloud condensation nuclei properties at a polluted site in southeastern China during the AMF-China Campaign. J. Geophys. Res., 116, D00K35, doi: 10.1029/2011JD016395.

Lohmann, U., and Feichter, J., 2005, Global Indirect Aerosol Effects: A Review. Atmos. Chem. Phys., 5,715-737.

Lu, Z, Zhang Q., and Streets D.G., 2011. Sulfur dioxide and primary carbonaceous aerosol emissions in China and India, 1996-2010. Atmos. Chem. Phys., 11, 9839-9864

Manoharan V. S, Kotamarthi R., Feng Y., and Cadeddu M. P., 2014. Increased absorption by coarse aerosol particles over the Gangetic-Himalayan region. Atmos. Chem. Phys., 14, $1159-1165$.

Moorthy, K. K., Sreekanth V., Chaubey Jai Prakash Gogoi Mukunda M., Babu S. Suresh, Kompalli Sobhan Kumar, Bagare S. P., Bhatt Bhuvan C., Gaur Vinod K., Prabhu T. P., and Singh N. S., 2011. Fine and ultrafine particles at a near-free tropospheric environment over the high-altitude station Hanle in the Trans-Himalaya: New particle formation and size distribution. J. Geophys. Res., 116, D20212, doi: 10.1029/2011JD016343.

Nishita, C., Osada K., Matsunaga K., and Iwasaka Y., 2007. Number-size distributions of free tropospheric aerosol particles at Mt. Norikura, Japan: Effects of precipitation and air mass transportation pathways. J. Geophys. Res., 112, D10213, doi: 10.1029/2006JD007969.

Padmakumari, B., Maheskumar R. S, Harikishan G., Morwal S. B., Prabha T. V., Kulkarni J. R., 2013. In situ measurements of aerosol vertical and spatial distributions over continental India during the major drought year 2009. Atmos. Environ., 80, 107-121.

Panday, A. K. and Prinn, R. G., 2009. Diurnal Cycle of air pollution in the Kathmandu Valley, Nepal: Observations. J. Geophys. Res., 114, D09305, doi: 10.1029/2008JD009777.

Panday, A. K., Prinn, R. G., and Schär, C., 2009. Diurnal cycle of air pollution in the Kathmandu Valley, Nepal: 2. Modeling results. J. Geophys. Res., 114, D21308, doi: 10.1029/2008JD009808.

Patidar V., Tripathi S. N., Bharti P. K., and Gupta T., 2012., First Surface Measurement of Cloud Condensation Nuclei over Kanpur, IGP: Role of Long Range Transport. Aeros. Sci. Tech., 46, 973-982.

Prabha T.V., Karipot A., Axisa D., Padmakumari B., Maheskumar R. S., Konwar M., Kulkarni J. R., and Goswami B. N., 2012, Scale interactions near the foothills of Himalaya during CAIPEEX. J. Geophys. Res., 117, D10203, 495 doi: 10.1029/2011JD0167.

Pruppacher, H. R. and Klett J. D., 1997. Microphysics of clouds and precipitation. Kluwer Academic Publishers, Dordrecht, 288-289. 
Raatikainen T., Hyvärinen A.-P., Hatakka J., T. Panwar S., Hooda R. K., Sharma V. P., Lihavainen H., 2014. The effect of boundary layer dynamics on aerosol properties at the Indo-Gangetic plains and at the foothills of the Himalayas, Atmos. Environ. 89, 548-555, http://dx.doi.org/10.1016/j.atmosenv.2014.02.058.

Ram Kirpa, Sarin M.M., Hegde P., 2008. Atmospheric abundances of primary and secondary carbonaceous species at two high-altitude sites in India: Sources and temporal variability. Atmos. Environ., 42, 6785-6796.

Ram Kirpa, Sarin M.M., Tripathi S.N., 2010. A 1 year record of carbonaceous aerosols from an urban site in the Indo-Gangetic Plain: Characterization, sources, and temporal variability. J. Geophys. Res., 115, D24313, doi: 10.1029/2010JD014188.

Ram Kirpa, Tripathi S. N., Sarin M. M. and Bhattu D. 2014. Primary and secondary aerosols from an urban site (Kanpur) in the Indo-Gangetic Plain: Impact on CCN, CN concentrations and optical properties. Atmos. Environ., 89 (2014) 655-663.

Ramanathan, V., Crutzen P. J., Kiehl J. T., Rosenfeld D., 2001. Aerosols, Climate and Hydrological Cycle. Science, 294, 2119-2124.

Robert, G. C., and Nenes, A., 2005. A Continuous Flow Streamwise Thermal gradient CCN Chamber for Atmospheric Measurements. Aeros. Sci. Tech., 39, 206-221.

Rose, D, S.S., Gunthe, Mikhailov E Frank, GP, U., Dusek, M.O., Andreae, U., Poschl, 2008. "Calibration and measurement uncertainties of continuous-flow cloud condensation nuclei counter (DMT-CCNC): CCN activation of ammonium sulfate and sodium chloride aerosol particles in theory and experiment." Atmos. Chem. Phys., 8, 1153-1179.

Rosenfeld, D., Lohmann Ulrike, Raga Graciela B., O'Dowd Colin D., Kulmala Markku, Fuzzi Sandro , Reissell Anni , Andreae Meinrat O., 2008. Flood or Drought: How do Aerosols Affect Precipitation?. Science, 321, 1309.

Sarangi T., Naja Manish, Ojha N., Kumar R., Lal S., Venkataramani S., Kumar A., Sagar R. and Chandola H. C., 2014. First simultaneous measurements of ozone, $\mathrm{CO}$ and $\mathrm{NO}_{\mathrm{y}}$ at a high altitude regional representative site in the central Himalayas. J. Geophys. Res., doi: 10.1002/2013JD020631.

Seinfeld, J. H. and Pandis, S. N., 1998. Atmospheric Chemistry and Physics: From Air Pollution to Climate Change. A Wiley Interscience Publication, USA, 1998.

Sellegri, K. P. Laj, H. Venzac, J. Boulon, D. Picard, P. Villani, P. Bonasoni, A. Marinoni, P. Cristofanelli, and E. Vuillermoz et al., 2010. Seasonal variations of aerosol size distributions based on long-term measurements at the high altitude Himalayan site of Nepal Climate Observatory-Pyramid (5079 m), Nepal. Atmos. Chem. Phys., 10, 1067910690.

Shrestha P. Barros A. P., and Khlystov A., 2010. Chemical composition and aerosol size distribution of the middle mountain range in the Nepal Himalayas during the 2009 premonsoon season. Atmos. Chem. Phys., 10, 11605-11621.

Shrestha, P., Barros Ana P., Khlystov Andrei, 2013. CCN estimates from bulk hygroscopic growth factors of ambient aerosols during the pre-monsoon season over Central Nepal. Atmos. Environ., 67, 120-129.

Srivastava A. K., Tiwari S., Devara P. C. S., Bisht D. S., Srivastava Manoj K., Tripathi S. N., Goloub P., and Holben B. N., 2011. Pre-monsoon aerosol characteristics over the IndoGangetic Basin: Implications to climate impact. Ann. Geophys., 29, 789-804.

Srivastava Monika, Tripathi S. N., Dwivedi A. K., Dalai Rosalin, Bhattu Deepika, Bharti P. K., Jaidevi J. and Gupta Tarun, 2013. CCN closure results from Indian Continental Tropical Convergence Zone (CTCZ) aircraft experiment. Atmos. Res., 132-133, 322331. 
Tripathi, S. N., Dey Sagnik, Tare Vinod, Satheesh S. K., Lal Shyam and Venkataramani S., 2005. Enhanced layer of black carbon in a north Indian industrial city. Geophys. Res. Lett., 32, L12802, doi: .1029/2005GL022564.

Twomey, S., 1977. The Influence of Pollution on the Shortwave Albedo of Clouds. J. Atmos. Sci., 34, 1149-1152.

Venzac, H., Sellegri K., Villani P., Picard D., and Laj P., 2009. Seasonal variation of aerosol size distributions in the free troposphere and residual layer at the puy de Dome station, France. Atmos. Chem. Phys., 9, 1465-1478.

Yum, S. S., Hudson J. G., Song K. Y. and Choi B. C., 2005. Springtime cloud condensation nuclei concentrations on the west coast of Korea. Geophys. Res. Lett., 32, L09814, doi: 10.1029/2005GL022641.

Yum, S. S., Roberts G., Kim J. H., Song K., and Kim D., 2007. Submicron aerosol size distributions and cloud condensation nuclei concentrations measured at Gosan, Korea, during the Atmospheric Brown Clouds-East Asian Regional Experiment 2005. J. Geophys. Res., 112, D22S32, doi: 10.1029/2006JD008212. 
Table 1: Monthly statistics of CCN, CN and AR for $\mathrm{S}=0.31-0.33 \%$ and mixing height derived from HYSPLIT.

\begin{tabular}{|c|c|c|c|c|c|c|c|c|c|c|c|c|c|c|c|c|}
\hline \multirow{2}{*}{ Month } & \multicolumn{4}{|c|}{$\mathrm{N}_{\mathrm{CCN}}\left(\mathrm{cm}^{-3}\right)$} & \multicolumn{4}{|c|}{$\mathrm{N}_{\mathrm{CN}}\left(\mathrm{cm}^{-3}\right)$} & \multicolumn{4}{|c|}{$\mathrm{AR}=\mathrm{N}_{\mathrm{CCN}} / \mathrm{N}_{\mathrm{CN}}$} & \multicolumn{4}{|c|}{ Mixing Height (in meter) } \\
\hline & Mean \pm SD & Min & Med & $\operatorname{Max}$ & Mean \pm SD & Min & Med & Max & Mean \pm SD & Min & Med & Max & $\mathrm{Mean} \pm \mathrm{SD}$ & Min & Med & Max \\
\hline Jun & $925 \pm 601$ & 77 & 911 & 2454 & $2425 \pm 1112$ & 785 & 2420 & 4955 & $0.38 \pm 0.11$ & 0.11 & 0.40 & 0.56 & $672.62 \pm 553.56$ & 93.86 & 543.01 & 1546.92 \\
\hline Jul & $881 \pm 500$ & 257 & 733 & 2738 & $1874 \pm 776$ & 1062 & 1693 & 4951 & $0.47 \pm 0.11$ & 0.20 & 0.50 & 0.65 & $464.60 \pm 364.61$ & 91.52 & 373.61 & 1039.49 \\
\hline Aug & $684 \pm 396$ & 24 & 760 & 1400 & $1606 \pm 453$ & 702 & 1662 & 2427 & $0.42 \pm 0.18$ & 0.03 & 0.48 & 0.67 & $381.85 \pm 366.40$ & 64.29 & 296.46 & 866.44 \\
\hline Sep & $1233 \pm 677$ & 351 & 1045 & 2763 & $2304 \pm 904$ & 1323 & 1978 & 4577 & $0.54 \pm 0.12$ & 0.23 & 0.58 & 0.72 & $371.16 \pm 366.40$ & 25.26 & 214.90 & 1008.40 \\
\hline Nov & $2026 \pm 813$ & 739 & 1914 & 3649 & $3485 \pm 1062$ & 1954 & 3460 & 6555 & $0.60 \pm 0.12$ & 0.33 & 0.62 & 0.77 & $314.38 \pm 387.78$ & 13.83 & 20.76 & 1066.31 \\
\hline Dec & $1465 \pm 510$ & 670 & 1440 & 2574 & $3193 \pm 1065$ & 1332 & 3184 & 5808 & $0.52 \pm 0.11$ & 0.16 & 0.54 & 0.69 & $271.52 \pm 367.71$ & 12.82 & 16.32 & 1043.61 \\
\hline Jan & $1500 \pm 591$ & 144 & 1463 & 2739 & $3155 \pm 934$ & 876 & 3183 & 5648 & $0.49 \pm 0.10$ & 0.20 & 0.52 & 0.65 & $365.11 \pm 469.32$ & 35.39 & 56.33 & 1402.45 \\
\hline Feb & $1757 \pm 397$ & 880 & 1718 & 2531 & $3383 \pm 708$ & 1698 & 3308 & 4844 & $0.54 \pm 0.06$ & 0.41 & 0.55 & 0.64 & $401.31 \pm 497.93$ & 37.81 & 93.81 & 1490.72 \\
\hline Mar & $2065 \pm 476$ & 1253 & 1985 & 3247 & $4124 \pm 747$ & 2708 & 3944 & 5835 & $0.54 \pm 0.09$ & 0.40 & 0.52 & 0.74 & $548.36 \pm 638.77$ & 25.79 & 211.21 & 1921.10 \\
\hline
\end{tabular}


Table 2: Comparison of $\mathrm{N}_{\mathrm{CN}}, \mathrm{N}_{\mathrm{CCN}}$ and AR over Nainital during GVAX campaign along with those measured at high altitude sites.

\begin{tabular}{|c|c|c|c|c|c|}
\hline $\begin{array}{l}\text { Site Name } \\
\text { (Altitude) }\end{array}$ & Sampling Period & $\begin{array}{l}\mathrm{N}_{\mathrm{CCN}}\left(\mathrm{cm}^{-3}\right) \\
\text { Mean } \pm \mathrm{SD}\end{array}$ & $\begin{array}{l}\mathrm{N}_{\mathrm{CN}}\left(\mathrm{cm}^{-3}\right) \\
\text { Mean } \pm \mathrm{SD}\end{array}$ & $\begin{array}{l}\mathrm{AR} \\
\text { Mean } \pm \mathrm{SD}\end{array}$ & References \\
\hline $\begin{array}{l}\text { Nainital }(\sim 1958 m \\
\text { amsl) }\end{array}$ & $\begin{array}{l}\text { Jun 2011-Mar } 2012 \\
\text { Monsoon (JJA) } \\
\text { Winter (DJF) }\end{array}$ & $\begin{array}{l}1264 \pm 895 \\
836 \pm 618 \\
1590 \pm 892\end{array}$ & $\begin{array}{l}2619 \pm 1738 \\
1955 \pm 1271 \\
3211 \pm 1801\end{array}$ & $\begin{array}{l}0.49 \pm 0.19 \text { at } 0.31-0.33 \% \mathrm{~S} \\
0.42 \pm 0.20 \text { at } 0.31-0.33 \% \mathrm{~S} \\
0.52 \pm 0.17 \text { at } 0.31-0.33 \% \mathrm{~S}\end{array}$ & Present Study \\
\hline $\begin{array}{l}\text { Puy-de-Dome } \\
(1465 \mathrm{~m}), \text { France }\end{array}$ & $\begin{array}{l}\text { Jun-Jul } 2011 \\
\text { (Summer) } \\
\text { Jan-Feb } 2012 \\
\text { (Winter) } \\
\end{array}$ & $\begin{array}{l}200-2000 \\
50-3000\end{array}$ & $100-10000$ & $0.2-0.7$ at $0.24 \% \mathrm{~S}$ & Asmi et al., 2012 \\
\hline $\begin{array}{l}\text { Mt Sonnblick } \\
(3104 \mathrm{~m}) \text {, Austria }\end{array}$ & $\begin{array}{l}\text { September } 1995 \\
\text { July } 1996\end{array}$ & $\begin{array}{l}80-570(\text { mean }=243) \\
\text { at } 0.5 \% \mathrm{~S} \\
29-786(\text { mean }=402) \\
\text { at } 0.5 \% \mathrm{~S}\end{array}$ & & & Hitzenberger et al., 1999 \\
\hline $\begin{array}{l}\text { Storm Peak } \\
\text { Laboratory } \\
(3210 \mathrm{~m}), \\
\text { Northwestern } \\
\text { Colorado }\end{array}$ & March 2011 & $1-470$ & $400-2000$ & & Friedman et al., 2013 \\
\hline $\begin{array}{l}\text { Jungfraujoch ( } 3580 \\
\text { m), } \\
\text { Switzerland }\end{array}$ & May 2008 & $\begin{array}{l}0.1-600(149 \pm 171) \\
\text { at } 0.12 \% \mathrm{~S} \\
27-1582(568 \pm 401) \\
\text { at } 1.18 \% \mathrm{~S}\end{array}$ & $40-1720(550)$ & & Jurănyi et al, 2010 \\
\hline
\end{tabular}




\begin{tabular}{|c|c|c|c|c|c|c|}
\hline \multirow[t]{2}{*}{ Month } & $c$ & $\boldsymbol{k}$ & \multirow{2}{*}{$k(0.17-0.31)$} & \multirow{2}{*}{$k(0.31-0.46)$} & \multirow{2}{*}{$k(0.46-0.60)$} & \multirow{2}{*}{$k(0.60-0.75)$} \\
\hline & \multicolumn{2}{|c|}{$\mathrm{S}$ range $(0.17,0.31,0.46,0.60 \& 0.75)$} & & & & \\
\hline Jun & $1708 \pm 256$ & $0.57 \pm 0.11$ & 0.619 & 0.652 & 0.663 & 0.569 \\
\hline Jul & $1386 \pm 97$ & $0.45 \pm 0.08$ & 0.615 & 0.652 & 0.651 & 0.561 \\
\hline Aug & $1092 \pm 47$ & $0.45 \pm 0.04$ & 0.623 & 0.649 & 0.650 & 0.556 \\
\hline \multirow[t]{2}{*}{ Sep } & $1607 \pm 61$ & $0.39 \pm 0.03$ & 0.632 & 0.655 & 0.648 & 0.554 \\
\hline & \multicolumn{2}{|c|}{ S range $(0.10,0.22,0.33,0.48,0.63 \& 0.78)$} & $k(0.22-0.33)$ & $k(0.33-0.48)$ & $k(0.48-0.63)$ & $k(0.63-0.78)$ \\
\hline Nov & $3005 \pm 233$ & $0.73 \pm 0.06$ & 0.704 & 0.645 & 0.617 & 0.531 \\
\hline Dec & $3123 \pm 514$ & $1.13 \pm 0.13$ & 0.666 & 0.633 & 0.623 & 0.533 \\
\hline Jan & $3678 \pm 328$ & $0.87 \pm 0.11$ & 0.680 & 0.643 & 0.624 & 0.533 \\
\hline Feb & $3523 \pm 545$ & $1.06 \pm 0.15$ & 0.667 & 0.645 & 0.624 & 0.533 \\
\hline Mar & $5065 \pm 755$ & $1.24 \pm 0.12$ & 0.669 & 0.637 & 0.615 & 0.531 \\
\hline
\end{tabular}

Table 3: Monthly mean values of $\mathrm{c}$ and $k$ parameters at Nainital obtained from the power law fit (Eq. 1) for different $\mathrm{S}$ ranges.

\begin{tabular}{|c|c|c|c|c|c|c|}
\hline & \multicolumn{3}{|c|}{ Kanpur } & \multicolumn{3}{|c|}{ Nainital } \\
\hline & $\mathrm{S}=0.2 \%$ & $\mathrm{~S}=0.4 \%$ & $\mathrm{~S}=0.8 \%$ & $\mathrm{~S}=0.17 \%$ & $\mathrm{~S}=0.31 \%$ & $\mathrm{~S}=0.75 \%$ \\
\hline $\mathrm{N}_{\mathrm{CCN}}$ & $2408 \pm 1030$ & $3682 \pm 1093$ & $3868 \pm 944$ & $589 \pm 288$ & $927 \pm 397$ & $1265 \pm 499$ \\
\hline $\mathrm{N}_{\mathrm{CN}}$ & $9862 \pm 4694$ & $9862 \pm 4694$ & $9862 \pm 4694$ & $2132 \pm 701$ & $2118 \pm 665$ & $2078 \pm 665$ \\
\hline AR & $0.30 \pm 0.08$ & $0.48 \pm 0.10$ & $0.70 \pm 0.24$ & $0.28 \pm 0.15$ & $0.42 \pm 0.14$ & $0.47 \pm 0.17$ \\
\hline
\end{tabular}

Table 4: Mean ( \pm SD) values of $\mathrm{N}_{\mathrm{CCN}}, \mathrm{N}_{\mathrm{CN}}$ and $\mathrm{AR}$ at Kanpur and Nainital during June to August 2011. 


\title{
Seasonal inhomogeneity in cloud precursors over Gangetic Himalayan region during GVAX campaign
}

\author{
U. C. Dumka ${ }^{1 *}$, Deepika Bhattu ${ }^{2}$, S. N. Tripathi ${ }^{2}$, D. G. Kaskaoutis ${ }^{3}$, and B. L. Madhavan ${ }^{4}$
}

${ }^{1}$ Aryabhatta Research Institute of observational sciences (ARIES), Nainital, India

${ }^{2}$ Department of Civil Engineering, Indian Institute of Technology, Kanpur, India

${ }^{3}$ Department of Physics, School of Natural Sciences, Shiv Nadar University, India

${ }^{4}$ Leibniz Institute for Tropospheric Research (TROPOS), Germany

[E-mail:dumka@aries.res.in; dimitris.kaskaoutis@snu.edu.in; snt@iitk.ac.in]

\section{Figure Captions:}

Figure 1:- Topography map with measuring sites referred in the text.

Figure 2:- Temporal variation of cloud condensation nuclei $\left(\mathrm{N}_{\mathrm{CCN}}\right)$, condensation nuclei $\left(\mathrm{N}_{\mathrm{CN}}\right)$ and activation ratio (AR) at four $(0.17-0.22 \%, 0.31-0.33 \%, 0.46-0.48 \%$ and $0.75-$ $0.78 \%$, respectively) S levels during June 2011 to March 2012.

Figure 3:- Monthly-mean diurnal variation of $\mathrm{N}_{\mathrm{CCN}}, \mathrm{N}_{\mathrm{CN}}$ and $\mathrm{AR}$ at $0.31-0.33 \% \mathrm{~S}$ during June, November, December and March. The vertical bars correspond to one standard deviation.

Figure 4:- Wind-rose diagram during monsoon (June - August), post-monsoon/autumn (September - November), winter (December - February) and pre-monsoon/spring (March only) based on measurements taken from June 2011 to March 2012. The grey circles show the $\%$ frequencies of counts per wind direction.

Figure 5:- Wind dependency of $\mathrm{N}_{\mathrm{CN}}\left(\mathrm{cm}^{-3}\right)$ at $0.31-0.33 \% \mathrm{~S}$.

Figure 6:- Same as in Fig. 5, but for $\mathrm{N}_{\mathrm{CCN}}$.

Figure 7:- Same as in Fig. 5, but for AR.

Figure 8:- Seasonal-mean variation of $\mathrm{N}_{\mathrm{CCN}}, \mathrm{N}_{\mathrm{CN}}$ and $\mathrm{AR}$ (\% in 4 quadrants: $0^{\circ}-90^{\circ}, 90^{\circ}$ $180^{\circ}, 180^{\circ}-270^{\circ}$ and $270^{\circ}-360^{\circ}$, respectively) at $0.31-0.33 \% \mathrm{~S}$. The vertical bars correspond to one standard deviation.

Figure 9:- Five-day HYSPLIT air mass back trajectories end at $500 \mathrm{~m}$ AGL at Nainital for the four seasons. The colour scale represents the travelling altitude by the air mass before reaching at the observation site.

Figure 10:- Seasonal-mean diurnal variation of the mixing height $(\mathrm{MH})$ over Nainital in box and whisker charts view. Box represents the $50 \%$ (from 25-75\%) of the values. Horizontal lines inside box represent mean (thin line) and median (thick line), respectively.

Figure 11:- (a) Monthly-averaged $\mathrm{N}_{\mathrm{CCN}}$ as a function of $\mathrm{S}$ and, (b) $\mathrm{N}_{\mathrm{CCN}}$ variation as a function of $\mathrm{S}$ for winter (December - February) and monsoon (June - August). 
Figure 12:- (a) $\mathrm{N}_{\mathrm{CCN}}$ and (b) $\mathrm{AR}$ at different $\mathrm{S}(0.31-0.33 \%, 0.46-0.48 \%$ and $0.75-0.78 \%$, respectively) levels as a function of $\mathrm{N}_{\mathrm{CN}}$, which is integrated over $500 / \mathrm{cm}^{3}$ bins. The vertical bars represent the standard deviation. The power law fits are shown as dotted lines.

Figure 13: Correlation between $\mathrm{N}_{\mathrm{CN}}$ and $\mathrm{N}_{\mathrm{CCN}}$ at two $\mathrm{S}$ levels 0.31-0.33 (black color) and 0.75-0.78 (red color) in each season at Nainital. The whole set of measurements was used in the correlations, while the slope and $\mathrm{R}^{2}$ values of the linear regressions are given for each case.

Figure 14: Scatter plot between $N_{C N}$ and $N_{C C N}$ at five $S$ levels during winter (DecemberJanuary; red color) and monsoon (June-August; black color). The dash and solid lines shows the linear least square fits between $\mathrm{N}_{\mathrm{CN}}$ and $\mathrm{N}_{\mathrm{CCN}}$. The slope and $\mathrm{R}^{2}$ values of the linear regressions are also given in each panel.

Figure 15:- Daily average values of $\mathrm{N}_{\mathrm{CCN}}(\mathrm{a}), \mathrm{N}_{\mathrm{CN}}$ (b) and $A R$ (c) in Kanpur and Nainital during June to August 2011. For all the graphs the $S$ level at Kanpur is $0.2 \%$ and at Nainital $0.17 \%$. The boxes correspond to $50 \%(25-75 \%)$ of the values and the vertical bars correspond to one standard deviation. The solid lines into the boxes stand for the mean.

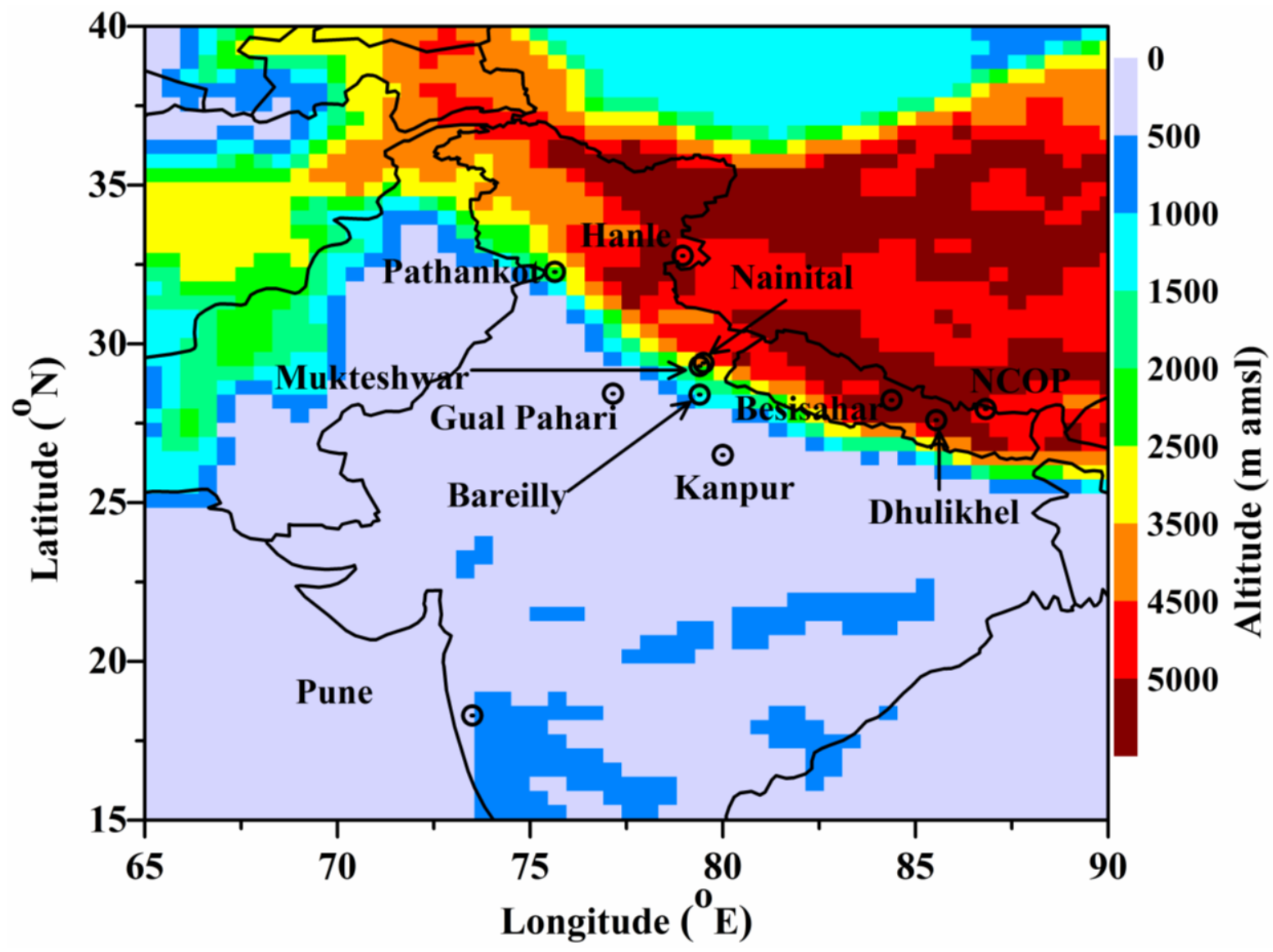

Figure 1 


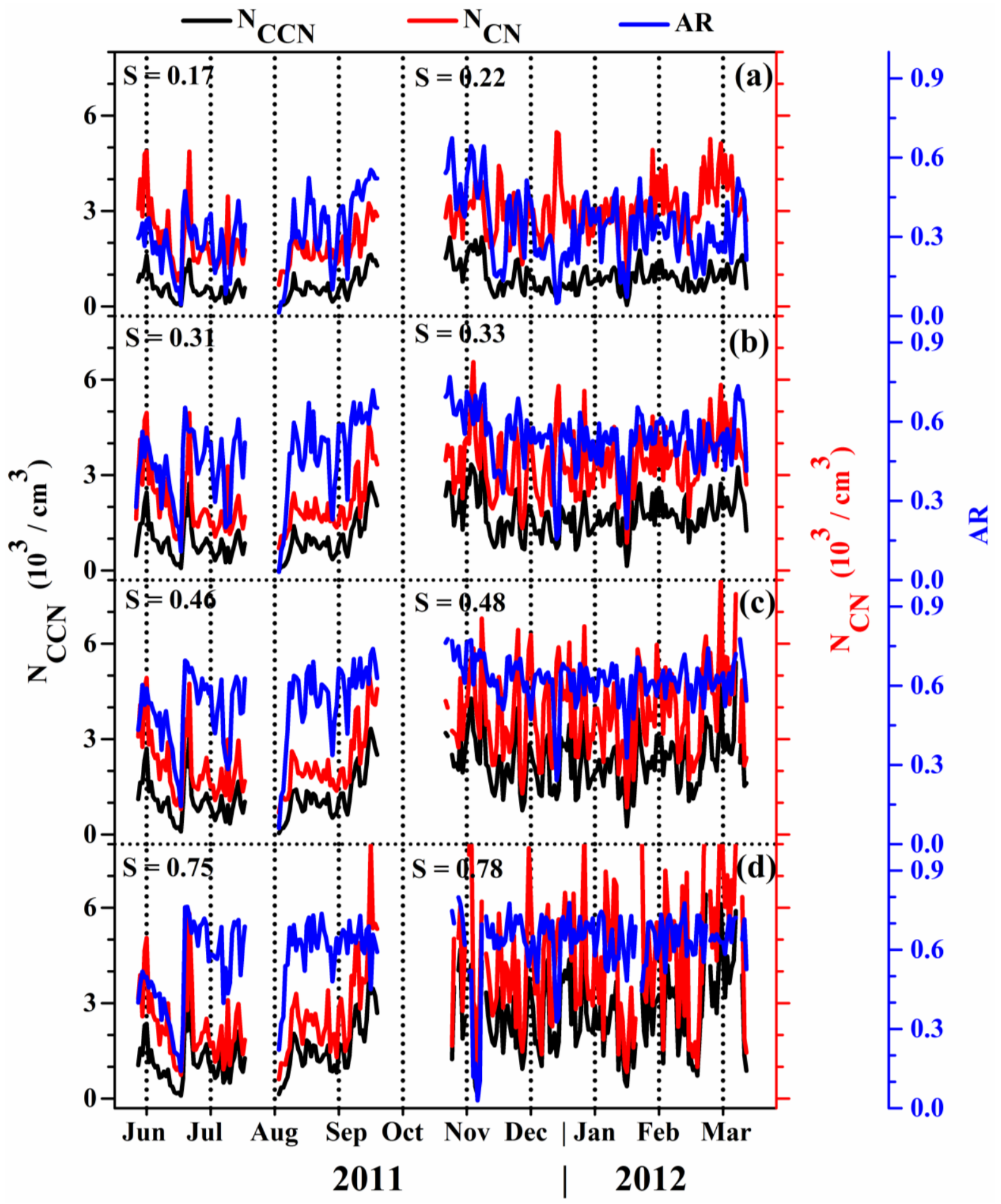

Figure 2 

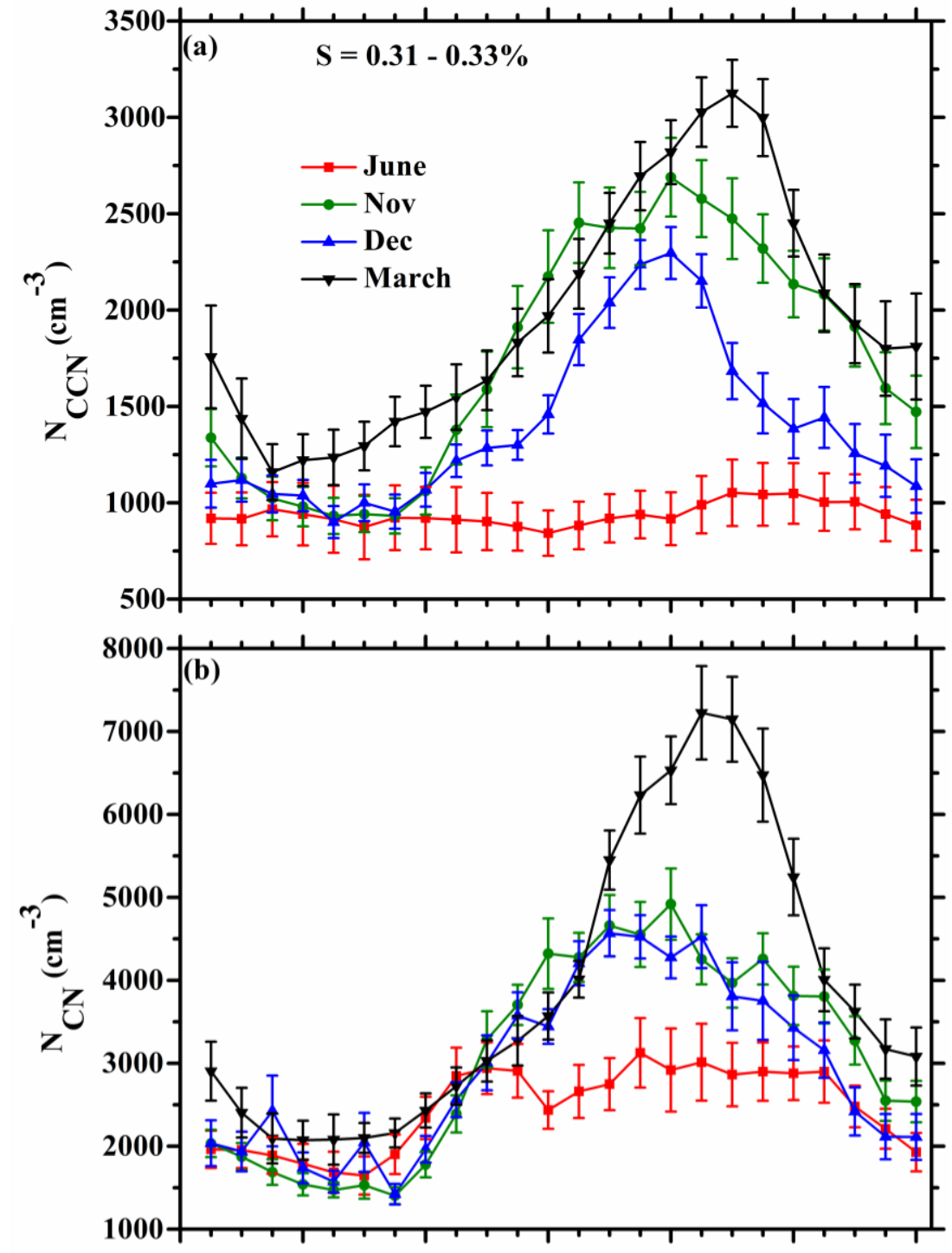

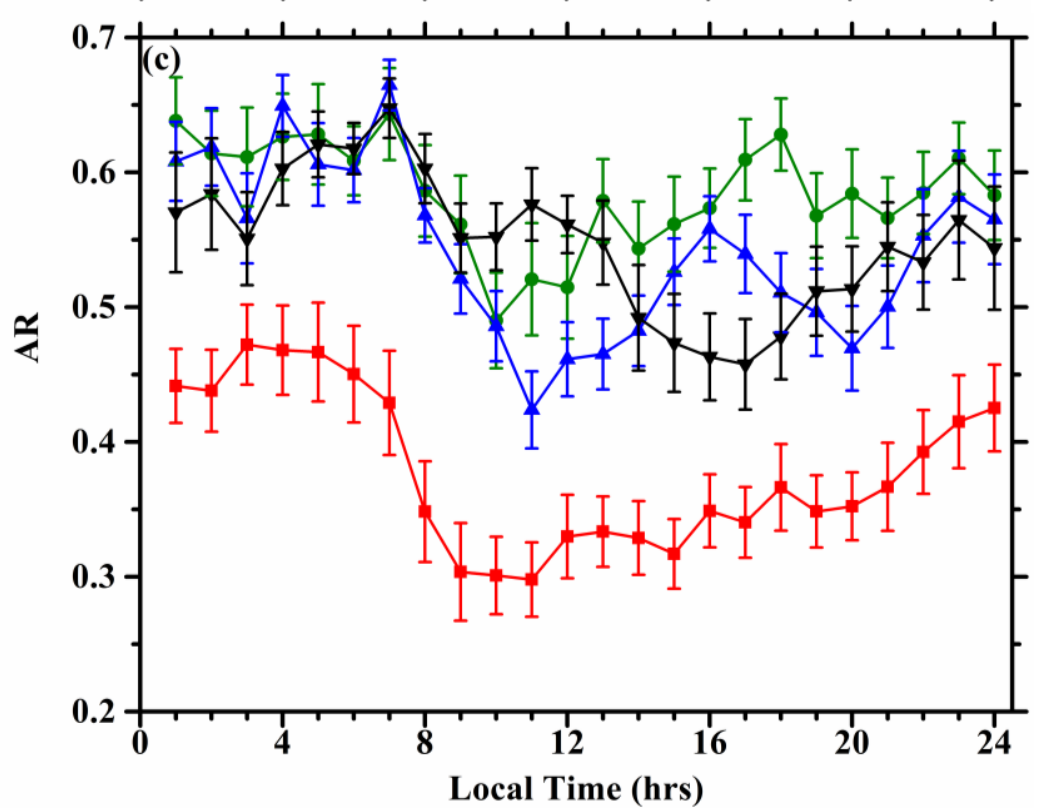

Figure 3

Page 4 of $\mathbf{1 6}$ 

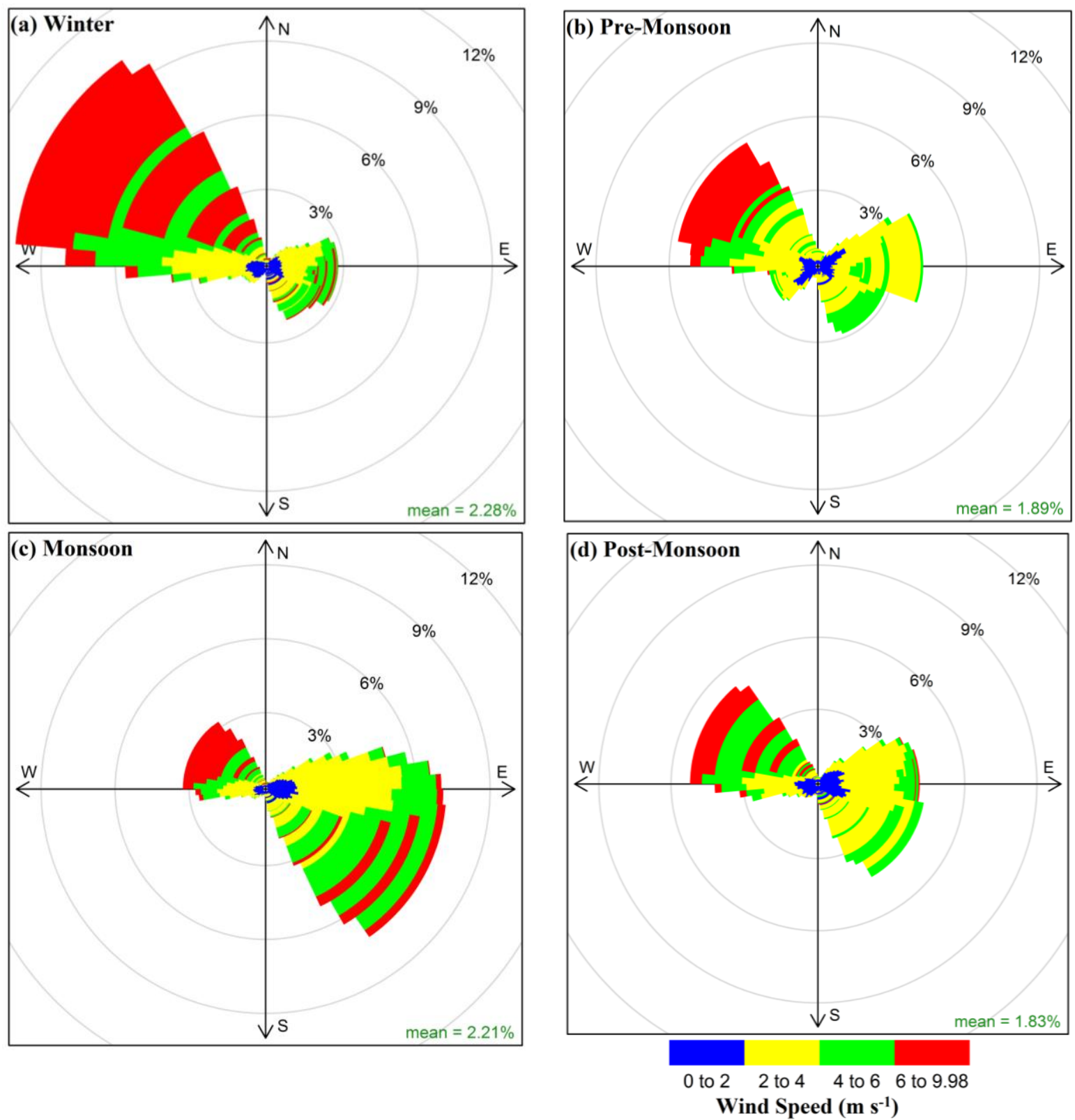

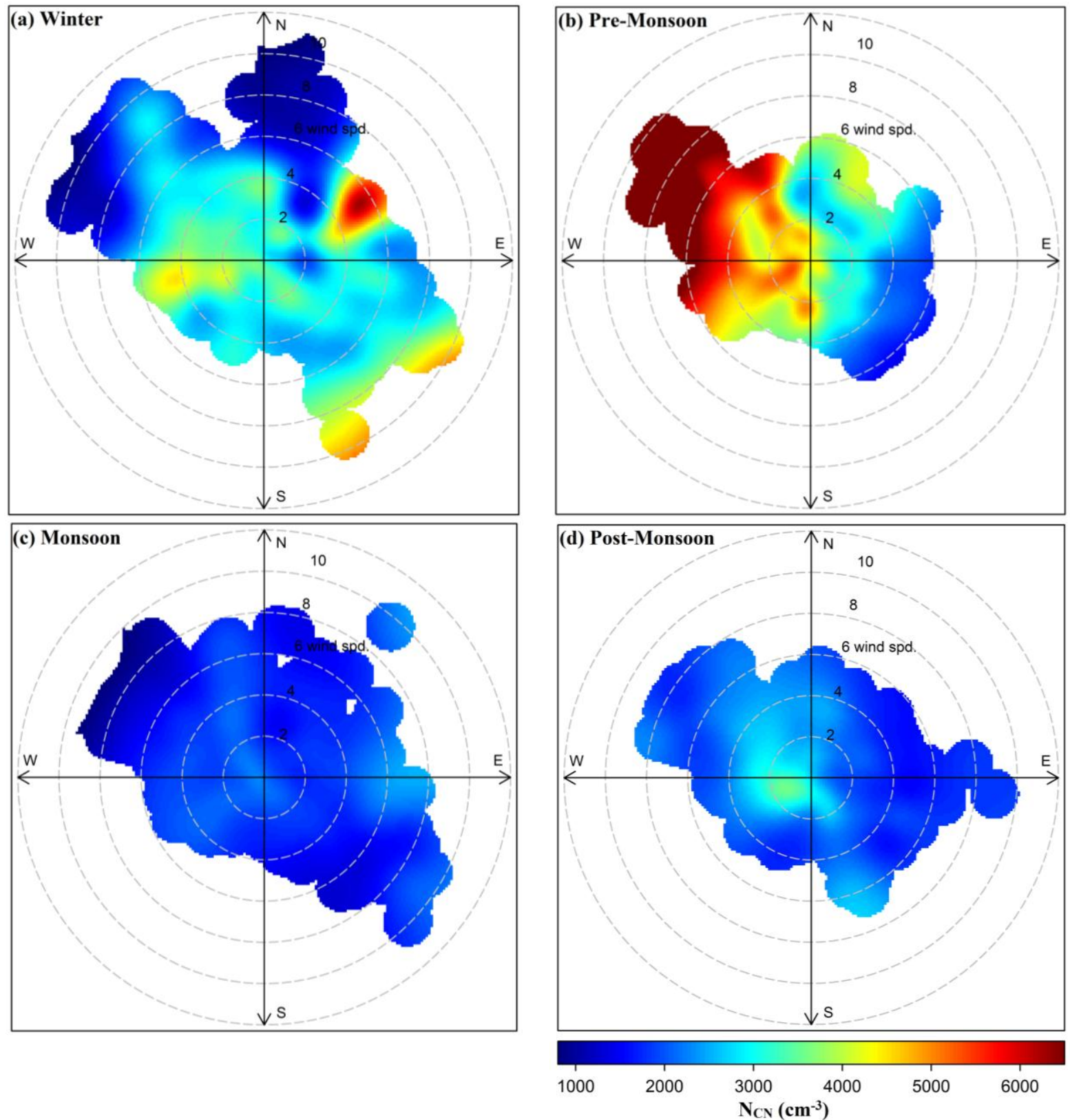

Figure 5 

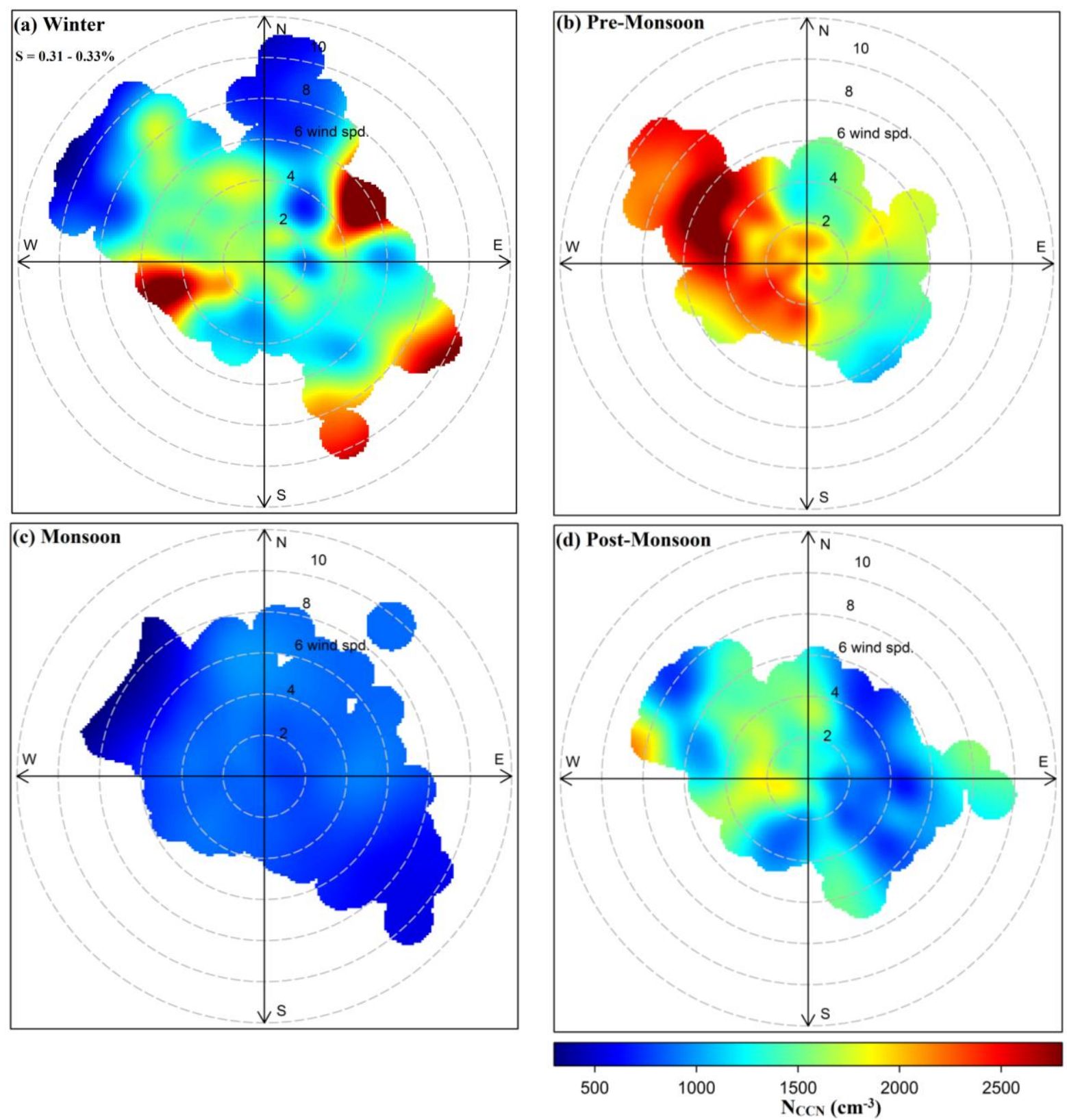

Figure 6 

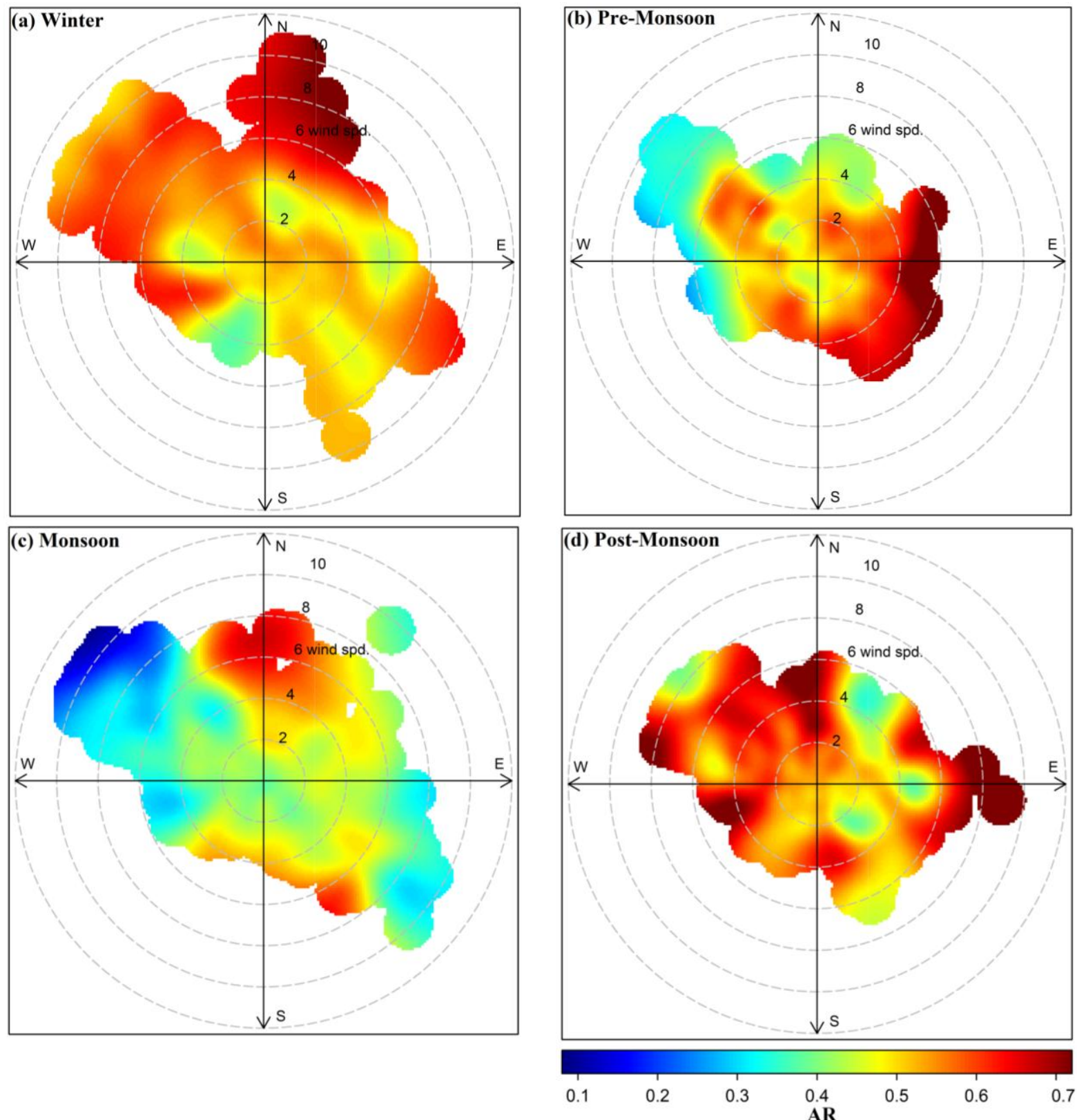

Figure 7 


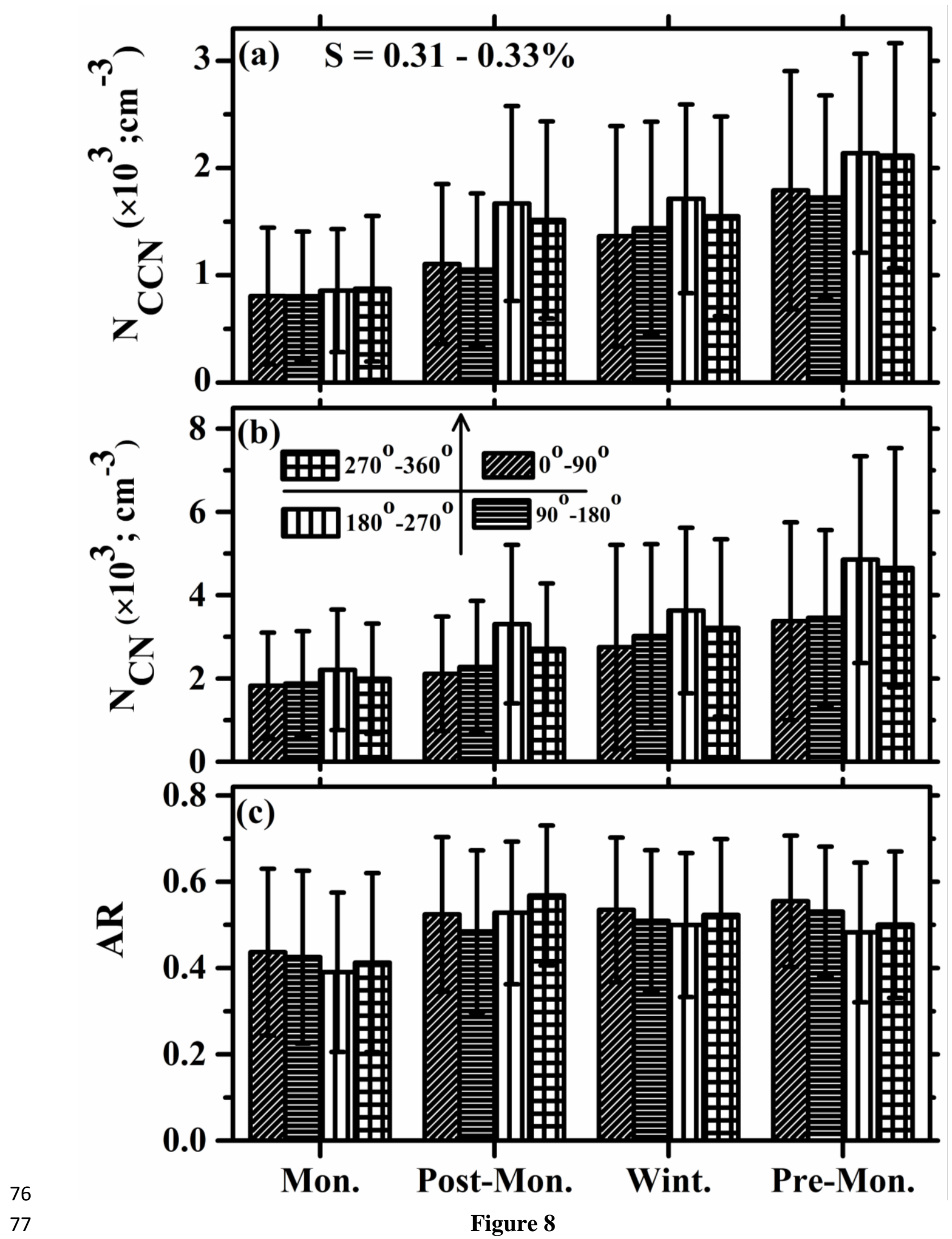

Page 9 of 16 


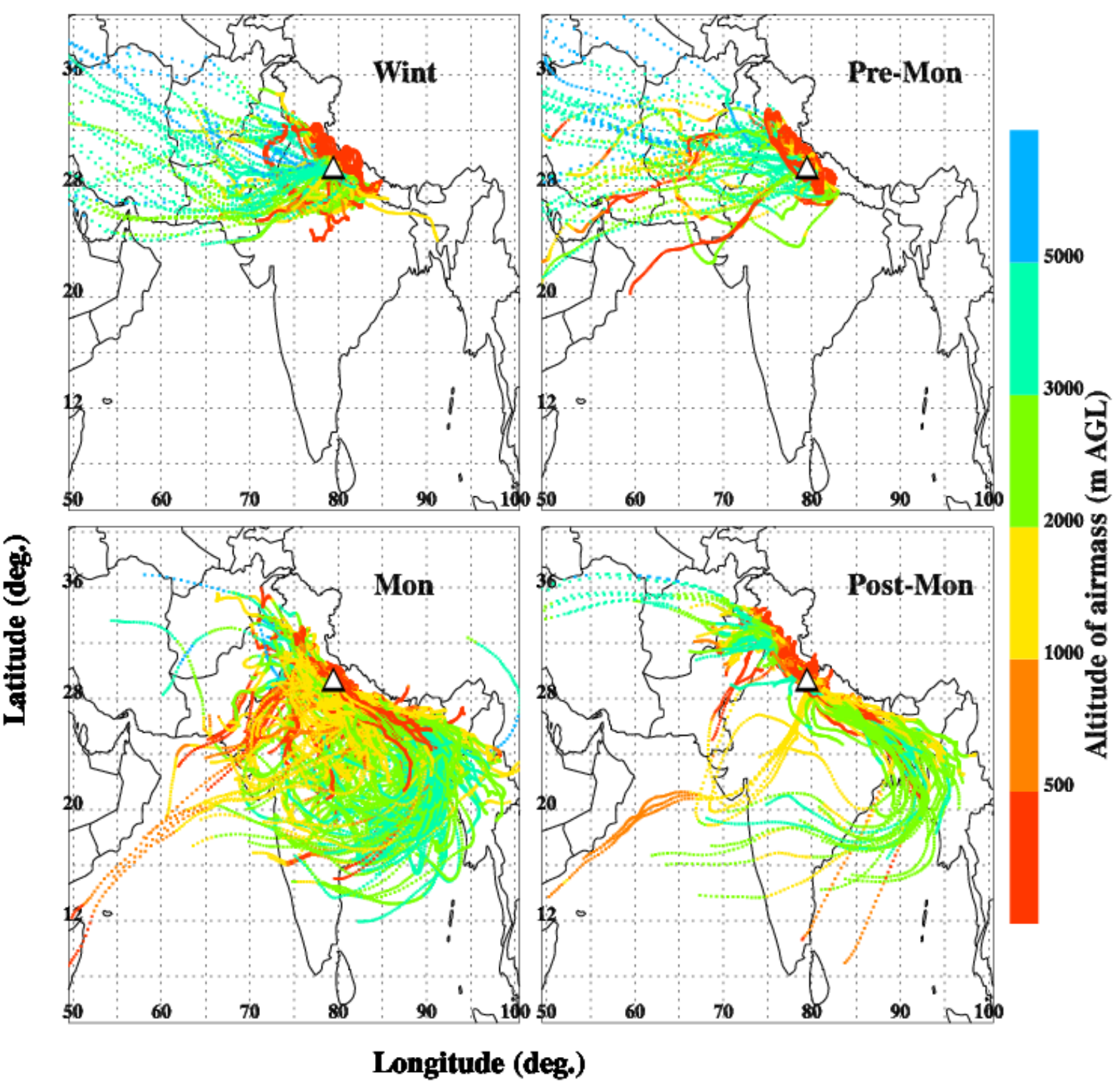

Figure 9 

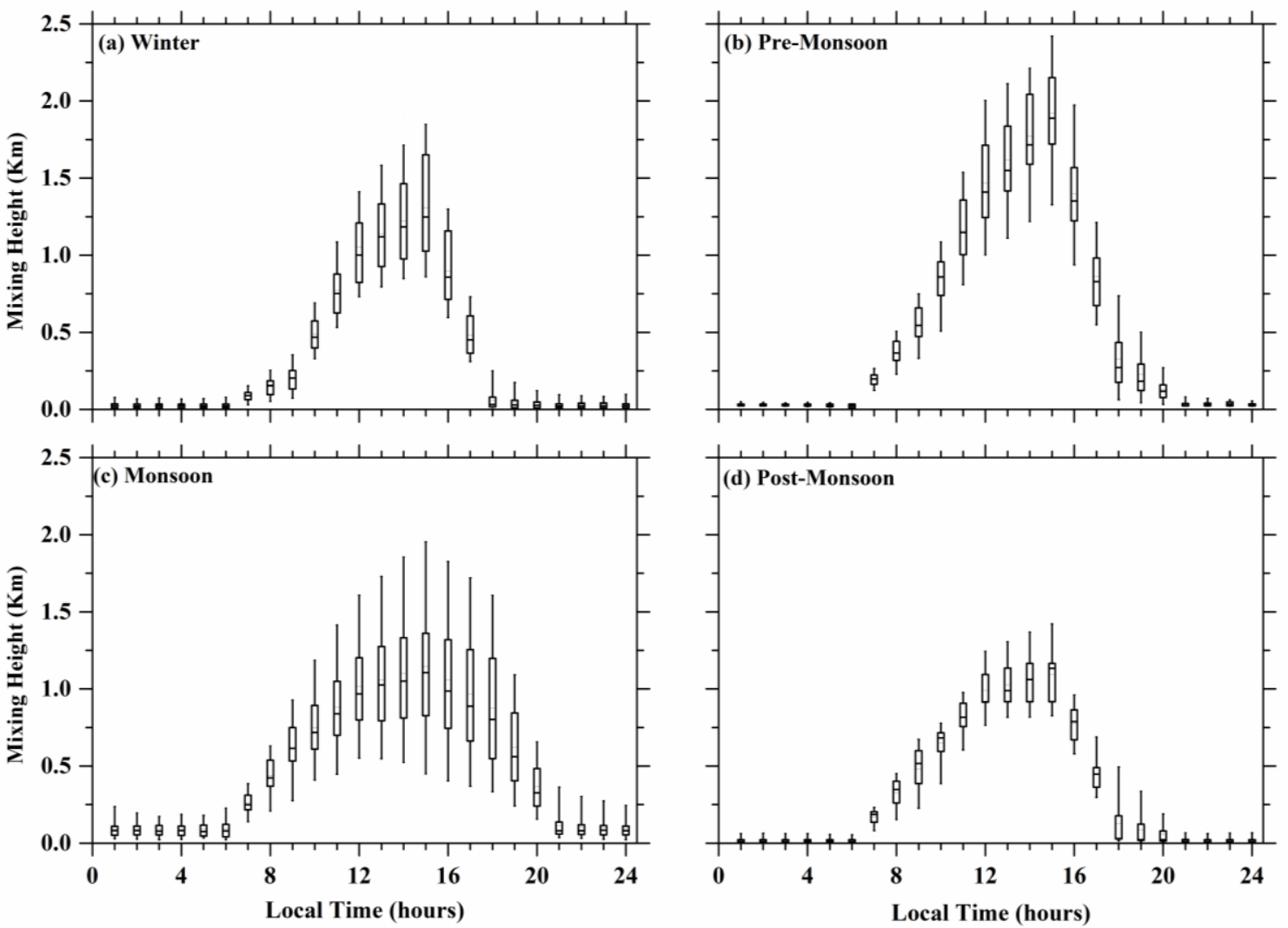

80

81

Figure 10 


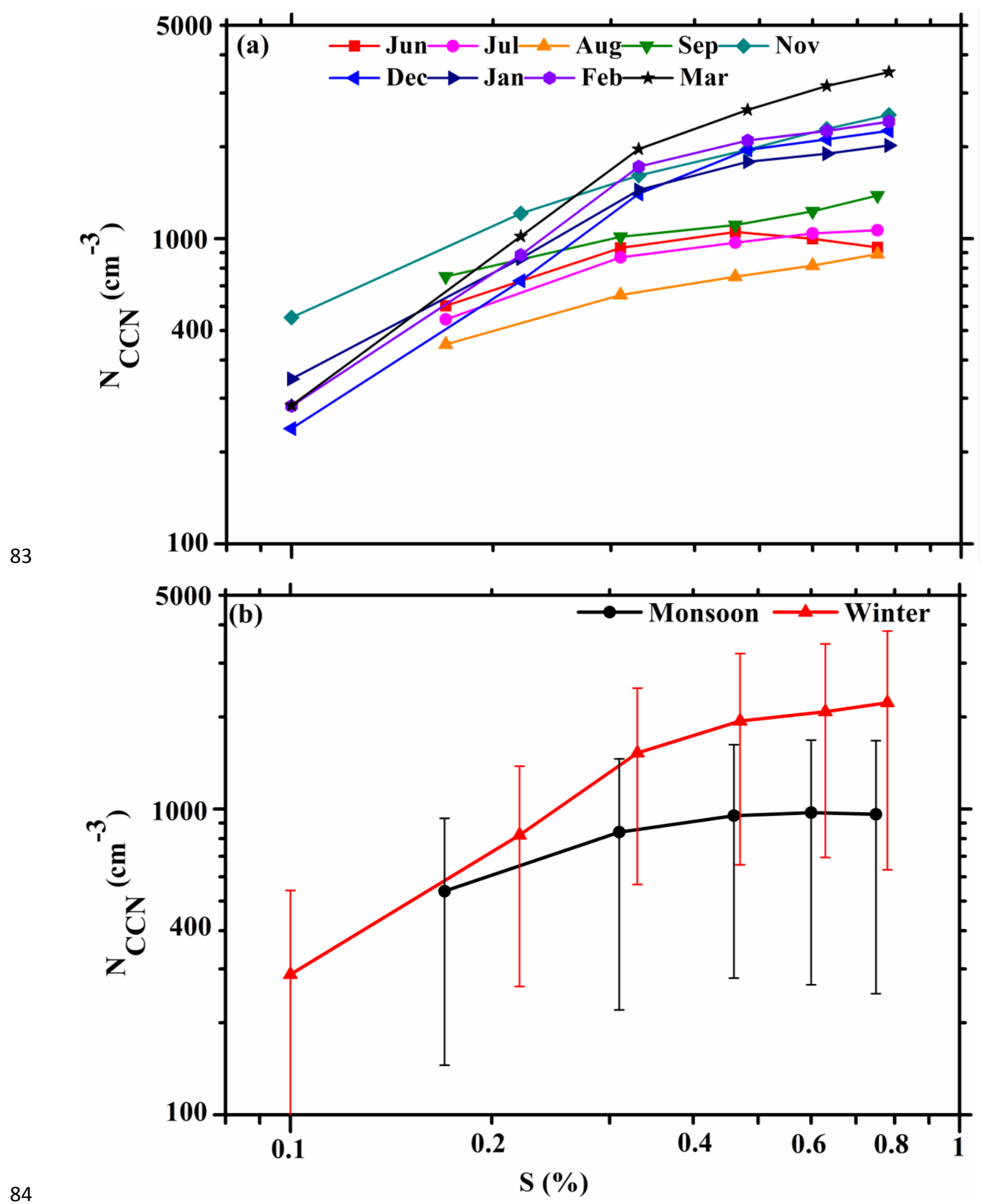




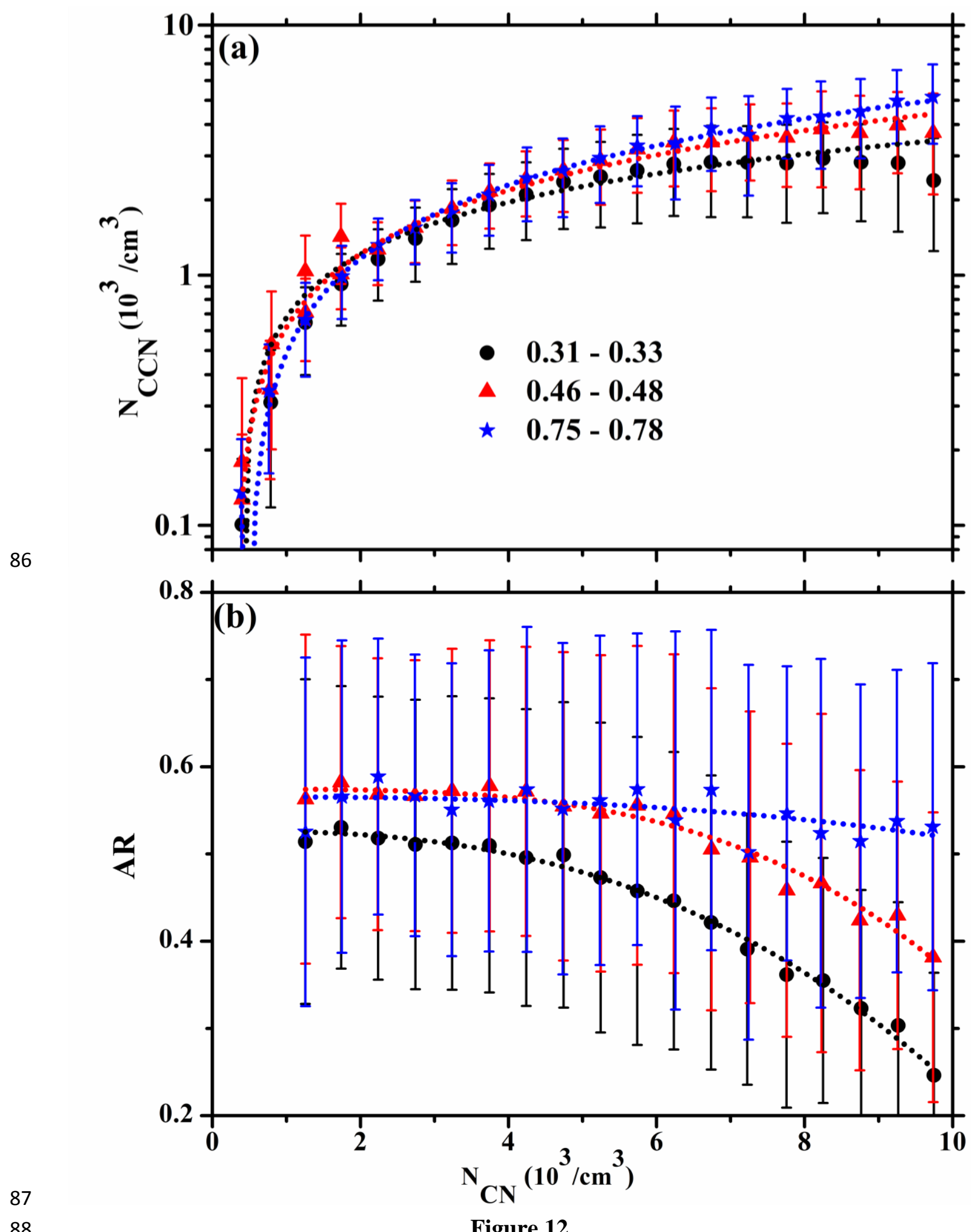



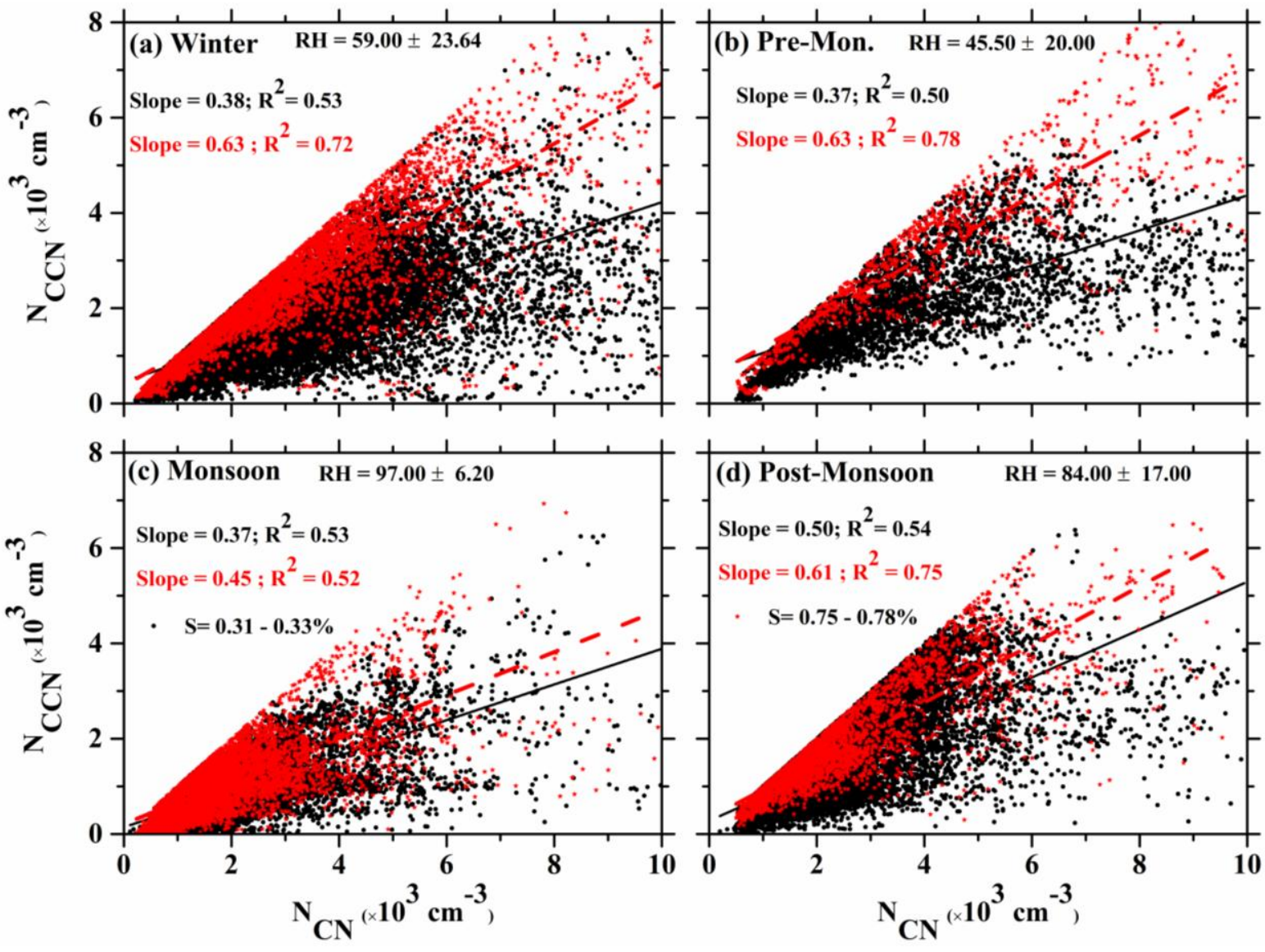

Figure 13 

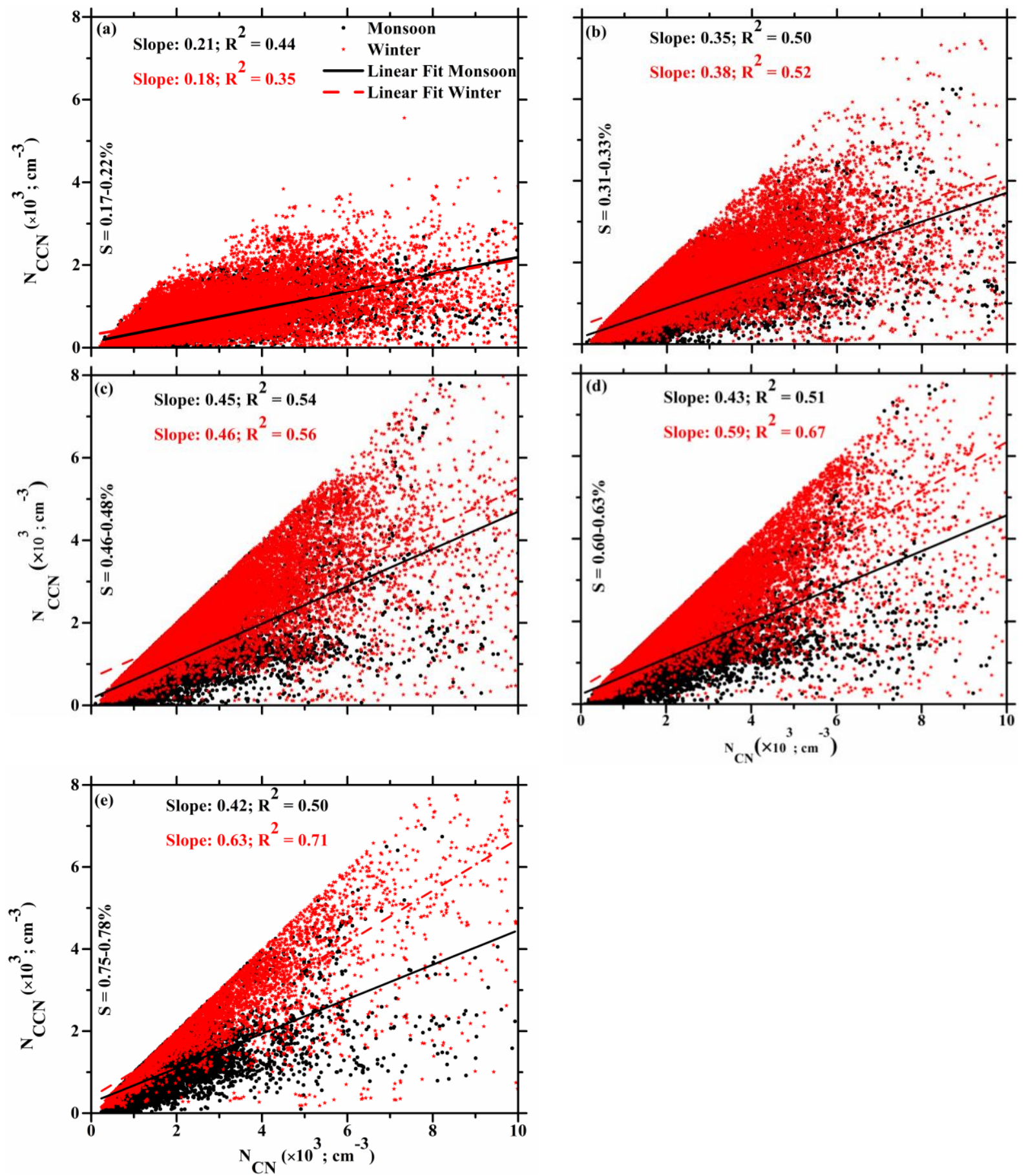

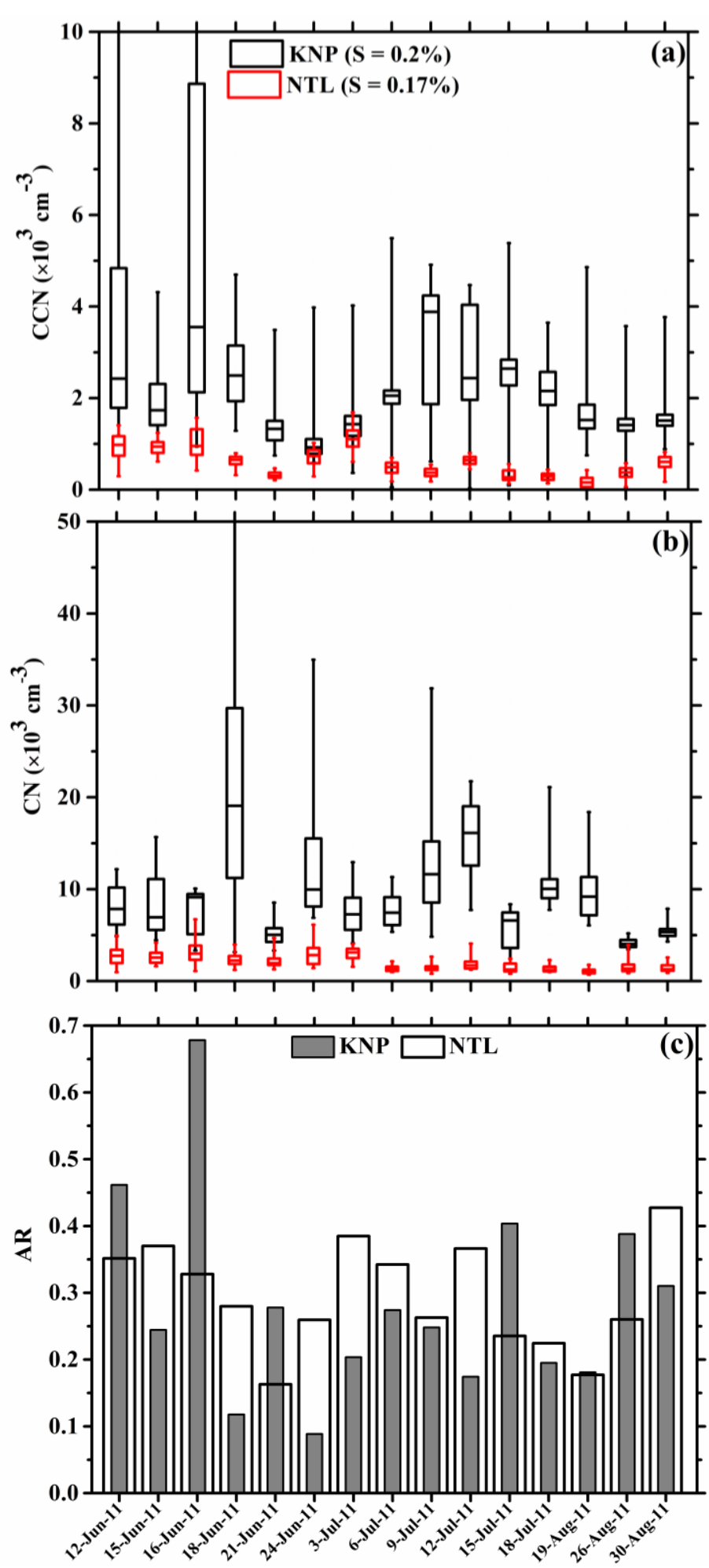

Figure 15 